ISSN : 1978-4333, Vol. 03, No. 01

\title{
Modal Sosial Dan Ketahanan Pangan Rumah Tangga Miskin Di Kecamatan Tanah Sareal Dan Kecamatan Bogor Timur, Kota Bogor) ${ }^{1}$
}

\author{
Alfiasari $^{2}$, Drajat Martianto ${ }^{3}$, dan Arya H. Dharmawan ${ }^{4}$
}

\begin{abstract}
ABSTRAK
Nilai sosial yang terpelihara baik seperti kepercayaan, jaringan sosial, dan norma sosial menjadi hal yang menguntungkan bagi interaksi antar anggota masyarakat. Tulisan ini bertujuan untuk menganalisis kondisi modal sosial dan potensinya dalam menguatkan ketahanan pangan pada rumah tangga miskin di lokasi penelitian. Desain penelitian yang digunakan adalah cross sectional study. Penelitian ini dilakukan di Kelurahan Kedung Jaya, Kecamatan Tanah Sareal dan Kelurahan Tajur, Kecamatan Bogor Timur. Penelitian ini menunjukkan bahwa kecukupan modal sosial lebih terlihat di Kelurahan Kedung Jaya, dan keberadaan modal sosial tersebut berpotensi dalam menentukan ketahanan pangan rumah tangga miskin. Rumah tangga yang mempunyai kepercayaan lebih tinggi dalam menjalin hubungan tanpa rasa saling curiga, mempunyai kepercayaan lebih tinggi dalam menjaga lingkungan tetap langgeng (sustain), mempunyai hubungan sosialnya lebih banyak dalam pemenuhan kebutuhan pangan rumah tangganya, dan istrinya bukan penduduk asli lingkungan tempat tinggal merupakan rumah tangga yang mempunyai tingkat ketahanan pangan lebih baik.
\end{abstract}

Kata kunci : modal sosial, ketahanan pangan rumah tangga, rumah tangga miskin

\section{PENDAHULUAN}

Kemiskinan bukan saja milik masyarakat pedesaan. Masyarakat yang tinggal di wilayah perkotaan pun tidak luput dari kemiskinan. Pertumbuhan yang cepat di daerah-daerah perkotaan dihadapkan pada sebuah tantangan baru, yaitu penyebaran dan peningkatan kemiskinan di daerah perkotaan (urban). Kota merupakan simbol kemajuan peradaban, ekonomi, dan ilmu pengetahuan. Pusat kota telah menjadi sebuah "magnet" yang menarik orang untuk menggabungkan beragam kreativitas, menciptakan bentuk-bentuk baru dalam interaksi sosial maupun perkumpulanperkumpulan kolektif (Beall 2000). Kota telah begitu menariknya, bukan hanya

1 Sebagian dari tulisan hasil penelitian "ANALISIS KETAHANAN PANGAN RUMAH TANGGA MISKIN DAN PERANAN MODAL SOSIAL (Studi Kasus pada Rumah Tangga Miskin di Kecamatan Tanah Sareal dan Kecamatan Bogor Timur, Kota Bogor)"

2 Departemen Ilmu Keluarga dan Konsumen, Fakultas Ekologi Manusia IPB

3 Departemen Gizi Masyarakat, Fakultas Ekologi Manusia IPB

4 Departemen Komunikasi dan Pengembangan Masyarakat, Fakultas Ekologi Manusia IPB 
penduduk asli yang bertambah populasinya namun juga arus urbanisasi pun semakin tinggi. Pertumbuhan penduduk yang pesat dan persaingan untuk bertahan hidup yang lebih besar menyebabkan kesenjangan sosial di masyarakat perkotaan lebih terlihat jelas dibandingkan di daerah pedesaan (Maxwell et al. 2000).

BPS mencatat bahwa angka kemiskinan Indonesia di daerah perkotaan pada tahun 1980 mencapai angka 29.04\%, lebih tinggi daripada angka kemiskinan di pedesaan (28.42\%). Angka tersebut menurun pada tahun 1990, yaitu $16.75 \%$ di perkotaan dan $14.33 \%$ di pedesaan. Kondisi tersebut menunjukkan bahwa pada era 1980-an hingga 1990-an, angka kemiskinan di daerah perkotaan justru lebih tinggi daripada di daerah pedesaan. Hanya saja, pada tahun 1996 angka kemiskinan di daerah perkotaan menunjukkan penurunan yang cukup drastis yaitu mencapai $9.71 \%$, dan lebih rendah daripada angka kemiskinan di daerah pedesaan (12.30\%). Krisis ekonomi yang terjadi pada tahun 1997 menyebabkan angka kemiskinan di Indonesia kembali naik, dan pada tahun 2004 mencapai 12.13\% di daerah perkotaan dan $20.11 \%$ di daerah pedesaan (BPS 2005).

Bagi rumah tangga miskin khususnya yang tinggal di daerah perkotaan, keberadaan modal berupa uang (financial capital) dan modal alam (natural capital) cukup terbatas. Mereka tidak mempunyai cukup uang untuk membeli kebutuhan pangan secara cukup baik jumlah maupun mutunya. Begitu pula dengan modal alam, padatnya pemukiman penduduk di daerah perkotaan menyebabkan lahan yang dapat dimanfaatkan rumah tangga untuk menghasilkan sumber bahan pangan secara langsung juga terbatas. Selain itu, keterbatasan akses terhadap sumberdaya fisik seperti pelayanan kesehatan publik, pelayanan transportasi publik, dan fasilitasfasilitas pelayanan sosial lainnya seringkali dialami oleh rumah tangga miskin. Kondisi tersebut pada akhirnya menyebabkan kualitas modal manusia yang ada pun menjadi terbatas kemampuannya untuk melakukan upaya-upaya optimal dalam rangka meningkatkan kesejahteraannya. Keterbatasan modal berupa uang, modal alam, modal fisik, dan modal manusia tersebut membutuhkan pendorong yang mampu membuat masyarakat miskin tetap dapat bertahan hidup bahkan memperbaiki tingkat kesejahteraannya dengan keterbatasan berbagai modal yang dimilikinya.

Kadangkala, meskipun tidak mempunyai uang ataupun hasil pertanian yang memadai, penduduk miskin khususnya yang tinggal di daerah pedesaan masih bisa mengandalkan bantuan dari lingkungannya untuk dapat memenuhi kebutuhan pangan rumah tangganya. Nilai sosial yang terpelihara baik seperti kerjasama, kepercayaan, maupun saling menolong yang terjalin antar masyarakat apabila ada yang mengalami kesulitan menjadi hal yang menguntungkan bagi interaksi antar anggota masyarakat. Ritme kehidupan yang serba cepat dan tuntutan untuk bertahan hidup (survive) di dalam kedinamisan pertumbuhan daerah perkotaan menyebabkan nilai sosial tersebut seringkali menjadi memudar, bergeser dengan nilai-nilai individualistis. Kepercayaan, kerjasama, nilai budaya, kebersamaan sering dikenal sebagai bagian dari modal sosial. Modal sosial merupakan modal yang dimiliki oleh masyarakat sebagai hasil dari hubungan sosial yang terjalin di antara sesama anggota masyarakat. Robert Putnam, salah satu pelopor modal sosial, menyebutkan bahwa modal sosial mempunyai tiga pilar utama yaitu kepercayaan, norma dan nilai yang 
berlaku dalam masyarakat, serta jaringan sosial yang terjalin dalam sistem sosial (Winter 2000).

Tulisan ini merupakan bagian dari penelitian yang berjudul Analisis Ketahanan Pangan Rumah Tangga Miskin dan Peranan Modal Sosial (Studi Kasus pada Rumah Tangga Miskin di Kecamatan Tanah Sareal dan Kecamatan Bogor Timur, Kota Bogor). Dalam tulisan ini, pembahasan akan lebih difokuskan pada analisis keterkaitan ketahanan pangan dan modal sosial pada rumah tangga miskin di kedua lokasi penelitian.

\section{KERANGKA TEORITIS}

World Bank (2000) menyebutkan bahwa kemiskinan mempunyai empat dimensi, yaitu kurangnya kesempatan (lack of opportunity), rendahnya kemampuan (low capabilities), rendahnya tingkat ketahanan (low level of security), dan rendahnya pemberdayaan (empowerment). Ciri utama yang terlihat dari keempat dimensi kemiskinan tersebut adalah rendahnya pendapatan dan rendahnya kualitas sumberdaya manusia akibat ketidakmampuan orang miskin untuk mengakses kesempatan ekonomi dan pendidikan yang tersedia. Terkait dengan upaya-upaya penguatan ketahanan pangan rumah tangga miskin, hal mendasar yang menentukan tercukupinya pangan di tingkat rumah tangga baik jumlah maupun mutunya secara aman dan terjangkau adalah bagaimana mengubah sumberdaya-sumberdaya yang pada rumah tangga miskin dan lingkungannya menjadi modal-modal ekonomi yang dapat dimanfaatkan untuk mengakses pangan sesuai norma gizi yang berlaku. Modal ekonomi di sini tentu saja tidak hanya dalam bentuk uang yang kasat mata namun juga mencakup modal-modal lain yang ada di dalam masyarakat yang dalam kondisi tertentu dapat dikonversi dalam bentuk uang (Bourdieu dalam Winter 2000). Keterbatasan modal berupa uang, modal alam, modal fisik, dan juga modal manusia yang dimiliki rumah tangga miskin khususnya dalam pemenuhan pangan rumah tangga kiranya membutuhkan pendorong berupa sumberdaya yang dimiliki dari hubungan-hubungan sosial yang dimiliki anggota masyarakat, yang dikenal sebagai modal sosial.

Perdebatan secara akademik mengenai konsep modal sosial sebenarnya sudah dimulai pada awal 1980-an ketika seorang sosiolog Perancis bernama Pierre Bourdieu menelaah modal sosial pada masyarakat Eropa. Meskipun begitu, modal sosial mulai dikenal khalayak luas semenjak dipublikasikannya tulisan sosiolog asal Amerika bernama James Coleman yang berjudul Social Capital in The Creation of Human Capital pada tahun 1988. Perdebatan mengenai modal sosial mulai menghangat setelah Robert Putnam pada tahun 1993 mempublikasikan bukunya yang berjudul Making Democracy Work : Civic Traditions in Modern Italy yang melihat mata rantai perbedaan performance dari 20 pemerintah regional di Italia dalam perluasan kelembagaan-kelembagaan yang ada dalam masyarakat (Narayan 1998).

Layaknya ilmu pengetahuan yang terus berkembang, konsep modal sosial pun terus berkembang. Bourdieu mendifinisikan modal sosial sebagai keseluruhan sumberdaya baik yang aktual maupun potensial yang dimiliki seseorang berkat adanya jaringan hubungan secara kelembagaan yang terpelihara dengan baik, yang mana setiap anggota dalam kelembagaan tersebut memperoleh keuntungan dari 
modal yang dimiliki secara kolektif (Syahra et al. 2000, Winter 2000, http://www.viet-studies.org/ Bourdieu_capital.htm). Bourdieu juga menyebutkan bahwa modal sosial yang dibentuk oleh adanya jaringan-jaringan ini, pada kondisi tertentu dapat diubah menjadi modal ekonomi dan biasanya secara kelembagaan terlihat pada kelompok komunitas yang mempunyai kedudukan sosial yang tinggi dalam suatu masyarakat. Bourdieu menekankan bahwa modal sosial yang dibentuk oleh jaringan hubungan sosial, tidak begitu saja ada secara alami (natural given) atau begitu saja ada dalam suatu masyarakat (social given). Modal sosial merupakan hasil dari investasi strategi-strategi baik dari tindakan individu maupun kolektif dalam waktu sesaat ataupun berkelanjutan yang bertujuan untuk menstabilkan atau menghasilkan hubungan-hubungan sosial yang secara langsung berguna, baik dalam jangka pendek maupun jangka panjang (Winter 2000).

Sementara itu, James Coleman mendefinisikan modal sosial dari sudut pandang fungsi modal sosial itu sendiri, yang mana bukan ditekankan pada hubunganhubungan sosial (social relations) seperti definisi Bourdieu namun ditekankan pada struktur sosial (social structure). Coleman menyebutkan bahwa fungsi yang dapat diidentifikasi dari modal sosial adalah nilai dari aspek-aspek struktur sosial untuk memanfaatkan sumberdaya yang ada untuk mencapai tujuan dari anggotaanggotanya. Aspek-aspek struktur sosial yang dimaksud dalam definisi tersebut menunjuk pada sekumpulan kewajiban dan harapan, jaringan informasi, normanorma dan sanksi-sanksi yang efektif yang dapat memaksa atau menyemangati seseorang untuk bertingkah laku agar tetap eksis dalam menjaga hubungannya dengan orang lain. Jika Bourdieu tertarik pada pengembangan konsep modal sosial sebagai sumberdaya bagi modal ekonomi seseorang (economic capital), Coleman lebih tertarik untuk mengembangkan bagaimana modal sosial dalam jaringan keluarga dan komunitas sebagai sumberdaya bagi modal manusia (human capital) (Winter 2000).

Bila Bourdie dan Coleman mendefinisikan modal sosial dari ranah individu, keluarga, dan komunitas, Robert Putnam mendefinisikan modal sosial dari ranah regional dan nasional yang mana modal sosial dinilai sebagi pendorong dalam kelembagaan demokrasi dan pengembangan ekonomi. Menurut Putnam, rencana dan aksi penguatan ekonomi pasar dan kelembagaan demokratis di negara-negara berkembang hampir semuanya terpusat pada defisiensi modal manusia dan modal finansial, sehingga pendekatan yang digunakan untuk mengatasi masalah pembangunan di negara-negara berkembang lebih terfokus pada pemberian pinjaman dan pemberian pelatihan-pelatihan (technical assistance). Namun tidak banyak dibahas tentang defisiensi modal sosial yang terjadi, sehingga pendekatan yang ada tidak pernah membahas tentang bagaimana usaha-usaha untuk mendorong pembentukan modal sosial. Landasan pemikiran tersebut lah yang kemudian dianggap sebagai sesuatu yang menarik dan menjanjikan ketika teori-teori modernisasi dan kapitalisasi tidak mampu menghubungkan antara teori dengan aplikasinya. Menurut kelompok pengkritik modernisasi dan kapitalisasi, modal sosial merupakan sesuatu yang menarik dan menjanjikan karena menawarkan strategi-strategi potensial dalam rencana dan aksi penguatan ekonomi dan kelembagaan demokratis. Putnam mendefinisikan modal sosial sebagai kepercayaan (trust), norma (norms), dan jaringan (networks) yang memfasilitasi adanya 
kerjasama untuk mencapai keuntungan bersama (Woolcock 1998). Konsep modal sosial yang dikembangkan oleh Putnam pada ranah regional dan nasional ini memunculkan banyak kritikan. Apalagi penelitian yang dilakukan Putnam dilakukan di Italia yang identik dengan kekuatan "mafia". Modal sosial bagi komunitas "mafia" mungkin akan memberi keuntungan bagi keluarga "mafia", namun bagi orang di luar komunitas "mafia" modal sosial justru akan merugikan. Kerugian yang disebabkan oleh modal sosial tersebut yang oleh Putzel disebut sebagai dark side of sosial capital -sisi gelap modal sosial- (Winter 2000).

Di Indonesia, tradisi-tradisi yang bersifat lokalitas seperti gotong royong merupakan sebuah stok modal sosial yang dapat dijadikan aset menguntungkan dalam mengatasi krisis ekonomi yang terjadi akibat kemiskinan. Salah satu contohnya adalah tradisi "rereongan sarupi" yang terdapat di Propinsi Jawa Barat (Hikmat 2001). "Rereongan sarupi" yang dimanifestasikan dalam bentuk kerja sama dan gotong royong dalam pembangunan sosial, musyawarah dalam memecahkan masalah-masalah kemasyarakatan, saling menolong antar tetangga, dan saling mengingatkan apabila ada tetangga yang berbuat hal-hal yang merugikan masyarakat merupakan contoh modal sosial di dalam masyarakat. Contoh lain adalah tradisi "beas parelek" di Jawa Barat yang melibatkan aktivitas berupa pengumpulan beras sekitar satu sendok (satu "canting") setiap bulan. Hasil pengumpulan tersebut akan digunakan untuk menghadapi musim paceklik, menolong anggota masyarakat lainnya termasuk fakir miskin, mengatasi kelaparan, dan permasalahan sosial lainnya yang membutuhkan dana dan sarana yang siap pakai (Hikmat 2001). Sebuah penelitian yang menunjukkan manfaat ekonomis dari modal sosial pada pedagang angkringan di kota Yogyakarta (Brata 2004), juga menunjukkan bahwa modal sosial dapat menjadi aset dalam mengatasi kemiskinan sehingga rumah tangga tetap dapat memenuhi kebutuhan dasarnya, khususnya kebutuhan pangan. Manfaat ekonomis modal sosial terlihat dari hubungan sosial kekerabatan, yang mana pengalaman teman ataupun kerabat dekat yang telah menjadi pedagang angkringan tentang peluang usaha warung angkring merupakan salah satu faktor pendorong beberapa orang lebih memilih beralih profesi menjadi pedagang angkringan.

Sebagai contoh simpanan modal sosial (stock of social capital), tradisi "rereongan sarupi", "beas parelek", maupun modal sosial dalam jaringan pedagang angkringan di Kota Yogyakarta, bersifat potensial. Artinya, apabila nilai-nilai kepercayaan (trust), norma sosial, dan jaringan sosial yang ada di dalam komunitas tersebut mampu dimanfaatkan secara optimal maka simpanan modal sosial ini akan menguntungkan bagi kehidupan masyarakat, termasuk dalam memperbaiki kondisi ekonomi dan meningkatkan kesejahteraan dan lebih lanjut menjadi potensi dalam mengatasi ketidaktahanan pangan yang muncul sebagai dampak dari kemiskinan.

\section{METODE PENELITIAN}

\section{Desain, Lokasi, dan Waktu Penelitian}

Penelitian yang dilakukan untuk tulisan ini menggunakan desain penelitian cross sectional study. Penelitian dilakukan di wilayah Kota Bogor yaitu di Kelurahan Kedung Jaya, Kecamatan Tanah Sareal dan Kelurahan Tajur, Kecamatan Bogor Timur. Penetapan kedua kelurahan tersebut sebagai lokasi penelitian dilakukan secara purposive yang didasarkan pada jumlah penduduk miskin dan insiden status 
gizi kurang maupun buruk pada balita. Penelitian ini dilaksanakan selama 5 bulan pada bulan April sampai Agustus 2006.

\section{Teknik Penarikan Contoh}

Populasi dalam penelitian ini adalah seluruh rumah tangga miskin di Kota Bogor. Unit analisis terkecil dilakukan pada rumah tangga untuk variabel-variabel guna mengukur kondisi ketahanan pangan rumah tangga dan modal sosial. Rumah tangga miskin yang digunakan sebagai populasi penelitian ini adalah rumah tangga miskin di Kota Bogor yang didata oleh BPS Kota Bogor yang digunakan sebagai data dasar untuk mencairkan dana Bantuan Langsung Tunai (BLT) bagi rumah tangga miskin. Pendataan rumah tangga miskin memang selalu menimbulkan pro dan kontra, begitu juga pendataan yang dilakukan oleh BPS terkait dengan peluncuran dana BLT oleh pemerintah. Beberapa kasus memang muncul, beberapa rumah tangga yang sebenarnya tidak layak memperoleh BLT namun karena "human error" (kolusi dan nepotisme) akhirnya dapat memperoleh BLT. Sebaliknya, rumah tangga yang jauh lebih layak memperoleh dana BLT banyak yang tidak memperolehnya. Meskipun begitu, secara ilmiah penulis menilai bahwa variabel-variabel yang digunakan sebagai indikator rumah tangga miskin sebagai penerima BLT telah cukup lengkap, mulai dari pengukuran kondisi tempat tinggal, sumber air minum, sumber penerangan, bahan bakar untuk memasak sehari-hari, konsumsi makanan sumber protein hewani, kemampuan membeli pakaian, kemampuan berobat, lapangan pekerjaan utama kepala rumah tangga hingga kepemilikan tabungan (Lampiran 1). Berdasarkan alasan tersebut, rumah tangga miskin yang dimaksud dalam penelitian ini adalah rumah tangga hasil pendataan BPS yang digunakan untuk menentukan rumah tangga miskin penerima BLT. Di Kota Bogor, pencairan dana BLT Tahap I dilakukan pada bulan Oktober 2005. Oleh karenanya, data rumah tangga miskin yang digunakan dalam penelitian ini adalah hasil pendataan rumah tangga miskin pada awal tahun 2005 di Kota Bogor yang digunakan sebagai data acuan daftar penerima dana BLT Tahap I tahun 2005.

Pada pencarian data awal yang dilakukan, tidak diperoleh nama-nama keluarga dan penduduk miskin serta balita dengan status gizi kurang dan gizi buruk secara lengkap. Hal ini dikarenakan adanya keterbatasan pencatatan data pada instansiinstansi yang terkait dalam penelitian ini. Berdasarkan hal tersebut, penarikan contoh dalam penelitian ini menggunakan teknik cluster sampling. Cluster sampling merupakan teknik penarikan contoh yang bermanfaat ketika daftar secara lengkap tidak tersedia dari populasi (Agresti \& Finlay 1997). Berdasarkan data sekunder yang diperoleh, dua kelurahan yang diambil sebagai lokasi penelitian mewakili dua cluster dengan karakteristik berbeda. Berdasarkan data sekunder yang diperoleh dari instansi terkait, Kelurahan Kedung Jaya, Kecamatan Tanah Sareal mewakili cluster dengan karakteristik persentase keluarga dan penduduk miskin relatif rendah namun insiden gizi kurang dan buruk relatif tinggi. Kelurahan Tajur, Kecamatan Bogor Timur mewakili cluster dengan karakteristik persentase keluarga dan penduduk miskin relatif tinggi namun status gizi kurang dan buruk rendah. Kecamatan Tanah Sareal dipilih sebagai representasi dari bagian utara Kota Bogor dan Kecamatan Bogor Timur dipilih sebagai representasi dari bagian selatan Kota Bogor 
Keluarga miskin yang ada di masing-masing cluster dipilih secara acak untuk menentukan contoh terpilih penelitian ini berdasarkan data keluarga miskin yang tersedia (random sampling). Jumlah contoh rumah tangga dalam penelitian ini adalah 61 rumah tangga. Sebelum pengumpulan data dilakukan, sebenarnya telah dipilih secara acak masing-masing 34 rumah tangga penerima BLT dari dua RW yang ditetapkan di masing-masing kelurahan contoh sebagai rumah tangga contoh penelitian. Dikarenakan ada beberapa rumah tangga terpilih yang tidak bersedia menjadi contoh penelitian, maka jumlah akhir rumah tangga yang menjadi contoh penelitian ini adalah 33 rumah tangga dari Kelurahan Kedung Jaya, Kecamatan Tanah Sareal dan 28 rumah tangga dari Kelurahan Tajur, Kecamatan Bogor Timur sehingga keseluruhan sampel berjumlah 61 rumah tangga miskin. Alur penetapan lokasi dan contoh penelitian disajikan pada Lampiran 2.

Dalam pengumpulan data, penelitian yang dilakukan ini menggunakan instrumen kuesioner yang ditujukan untuk menggali informasi dari responden tingkat rumah tangga untuk mengidentifikasi kondisi ketahanan pangan rumah tangga dan modal sosial. Selain itu juga dilakukan wawancara mendalam (indepth interview) terhadap beberapa rumah tangga terpilih untuk memperoleh informasi lebih jauh dari responden guna menunjang data yang diperoleh dari hasil penilaian kuesioner.

\section{Pengolahan dan Analisis Data}

Data mengenai ketahanan pangan rumah tangg dan modal sosial yang diperoleh diolah dengan menggunakan program Microsoft Excell XP dan SPSS versi 10.5 for Windows. Data yang dihasilkan dalam penelitian ini disajikan dalam bentuk tabulasi silang dan juga dilakukan uji korelasi untuk melihat hubungan antar beberapa variabel. Kondisi ketahanan pangan rumah tangga diperoleh dengan menghitung Tingkat Kecukupan Energi (TKE) rumah tangga didasarkan pada data konsumsi pangan rumah tangga melalui metode food list record selama tujuh hari pengukuran. Metode food list record dipilih karena metode ini dapat merepresentasikan data yang ingin dikumpulkan dalam penelitian ini, yaitu data tentang asal pangan diperoleh, harga pangan, serta konsumsi pangan rumah tangga. Dalam metode ini, dilakukan wawancara kepada ibu rumah tangga tentang semua pangan yang dikonsumsi oleh semua anggota rumah tangga baik yang dimasak sendiri, hasil pembelian, maupun hasil pemberian. Jumlah pangan yang dikonsumsi oleh rumah tangga dicatat dalam URT (Ukuran Rumah Tangga) yang selanjutnya dikonversi menjadi satuan gram. Untuk dapat mengkonversi URT ke dalam gram, peneliti mengambil sampel pangan di warung-warung di sekitar rumah tangga miskin responden, yang biasanya digunakan sebagai tempat pembelian kebutuhan pangan sehari-hari. Data konsumsi hasil food list record selama tujuh hari tersebut kemudian diolah untuk mengetahui rata-rata konsumsi energi dan protein per kapita per hari, yang sebelumnya dikoreksi terlebih dahulu dengan unit konsumsi (consumption unit). Konsumsi unit merupakan penyetaraan dari jumlah kali makan utama (meals) dalam sehari (Kusharto \& Sa'diyyah 2005). Kondisi ini berdasarkan asumsi bahwa masyarakat Indonesia mempunyai kebiasaan makan utama sebanyak tiga kali dalam sehari yang setara dengan satu unit konsumsi. Oleh karenanya, apabila anggota rumah tangga responden penelitian ini hanya makan utama sebanyak dua kali di rumah maka unit konsumsinya adalah adalah $2 / 3$. Hal ini dilakukan untuk memperkecil kesalahan dalam penghitungan konsumsi per kapita maupun tingkat kecukupannya. 
Selanjutnya rata-rata konsumsi energi dan protein per kapita per hari tersebut dibandingkan dengan rata-rata kecukupan energi dan protein anggota rumah tangga responden yang dihitung berdasarkan jenis kelamin dan umur anggota rumah tangga responden. Hasilnya adalah tingkat kecukupan energi dan protein pada tingkat rumah tangga. Selanjutnya, tingkat kecukupan energi rumah tangga yang diperoleh dijadikan dasar untuk menentukan ketahanan pangan rumah tangga, yaitu : (a) rumah tangga tahan pangan bila tingkat kecukupan energi $\geq 90 \%$ dan (b) rumah tangga tidak tahan pangan bila tingkat kecukupan energi $<90 \%$.

Sementara itu, variabel modal sosial diukur dengan kepercayaan, jaringan sosial, dan norma sosial. Komponen modal sosial berupa kepercayaan dinilai dengan tujuh ukuran kepercayaan (Tabel 1). Sementara itu, komponen modal sosial berupa jaringan sosial dinilai berdasarkan sifat, basis/bentuk, luas, kedalaman, keragaman, dan permanency jaringan sosial. Komponen modal sosial lainnya, yaitu norma sosial dinilai dengan tiga ukuran yaitu keberadaan norma tidak tertulis, norma tradisional, dan norma agama yang diakui rumah tangga miskin responden sebagai landasan dalam menjalin hubungan sosial, baik dalam pemenuhan kebutuhan pangan maupun dalam pengasuhan balitanya. Selanjutnya, skor ketiga komponen modal sosial diperoleh dari komposit ukuran-ukuran tersebut (Tabel 1) dengan menggunakan standarisasi skor sebagai berikut:

$$
\text { Skor komponen modal sosial }=\frac{\text { nilai } \mathrm{x}-\text { skor minimum }}{\text { Skor maksimum-skor minimum }} \times 100
$$

\section{KONDISI KETAHANAN PANGAN RUMAH TANGGA MISKIN RESPONDEN}

Indonesia belum pernah melakukan survei konsumsi rumah tangga secara nasional hingga saat ini, sehingga informasi ketahanan pangan rumah tangga hanya dapat diketahui berdasarkan perkiraan pengeluaran pangan (Atmarita \& Fallah 2004). Berdasarkan data Susenas tentang pengeluaran pangan rumah tangga pada tahun 1995, 2000, dan 2003, Atmarita \& Fallah (2004) mengklasifikasikan kabupaten/kota di Indonesia berdasarkan 4 tingkat persentase pengeluaran makanan terhadap pengeluaran total, yaitu : (1) < 55\%; (2) 55-65\%; (3) 65-75\%; dan (4) 75\%. Hasilnya dapat diketahui bahwa pada tahun 2003 terdapat perbedaan yang mencolok antara desa dan kota, yang mana sebagian besar wilayah perkotaan $(56.2 \%)$ tergolong dalam kategori 55-65\% pengeluaran total yang digunakan untuk pangan. Sementara itu, sebagian besar wilayah pedesaan (63.0\%) tergolong dalam kategori $65-75 \%$ pengeluaran total yang digunakan untuk pangan. Apabila diasumsikan bahwa semakin besar persentase pengeluaran untuk pangan menunjukkan semakin rendahnya kemampuan ekonomi rumah tangga, maka kondisi tersebut menegaskan bahwa kemampuan ekonomi rumah tangga di wilayah perkotaan lebih tinggi di wilayah pedesaan.

Hasil penelitian ini menunjukkan bahwa rata-rata persentase pengeluaran pangan terhadap pengeluaran total rumah tangga adalah 59.13\% (Tabel 2). Hasil ini sesuai dengan kondisi perkotaan berdasarkan olahan data SUSENAS, yaitu bahwa sebagian 
besar wilayah perkotaan tergolong dalam kategori $55-65 \%$ pengeluaran total yang digunakan untuk pangan.

\section{Tabel 1. Peubah dan indikator modal sosial}

\begin{tabular}{|c|c|c|}
\hline Variabel & Indikator & Responden \\
\hline \multirow[t]{2}{*}{$\begin{array}{l}\text { Modal } \\
\text { sosial }\end{array}$} & $\begin{array}{l}\text { Kepercayaan : } \\
\text { 1. Kepercayaan diri rumah tangga dalam menjalin hubungan } \\
\text { sosial } \\
\text { 2. Kepercayaan rumah tangga untuk menjalin kerjasama } \\
\text { tanpa rasa saling curiga } \\
\text { 3. Kepercayaan rumah tangga bahwa kerjasama yang } \\
\text { dibangun dengan rumah tangga lain dapat membantu } \\
\text { pemenuhan kebutuhan pangan }\end{array}$ & \multirow[t]{2}{*}{$\begin{array}{l}\text { Kepala } \\
\text { Rumah } \\
\text { Tangga } \\
\text { (suami dan } \\
\text { istri) }\end{array}$} \\
\hline & $\begin{array}{l}\text { 4. Kepercayaan rumah tangga bahwa kerjasama yang } \\
\text { dibangun dengan rumah tangga lain dapat membantu } \\
\text { dalam pengasuhan balita } \\
\text { 5. Kepercayaan rumah tangga bahwa lingkungannya dapat } \\
\text { menciptakan kedamaian dan meredam kekacauan sosial } \\
\text { 6. Kepercayaan rumah tangga bahwa menjaga keeratan } \\
\text { hubungan di dalam lingkungannya adalah hal penting } \\
\text { 7. Kepercayaan rumah tangga bahwa lingkungannya dapat } \\
\text { menjaga hubungan di antara mereka tetap sustain } \\
\text { Jaringan sosial antar rumah tangga di dalam komunitas : } \\
\text { Sifat Jaringan : } \\
\text { - Formal } \\
\text { - Informal } \\
\text { Karakteristik Jaringan: } \\
\text { - Bentuk/basis hubungan sosial } \\
\text { - Luas } \\
\text { - Kedalaman dan keterbukaan } \\
\text { - Peragaman } \\
\text { Normanency } \\
\text { Aturan-aturan tidak tertulis dalam hubungan antar rumah } \\
\text { tangga di dalam komunitas } \\
\text { Nilai-nilai tradisional yang sudah ada turun temurun } \\
\text { Nilai-nilai agama yang diyakini dalam menjalin hubungan } \\
\text { sosial }\end{array}$ & \\
\hline
\end{tabular}

Ketahanan pangan rumah tangga dalam penelitian ini diukur dengan Tingkat Kecukupan Energi (TKE) yang didasarkan pada tingkat konsumsi pangan rumah tangga (Maxwell et al. 2000). Tabel 3 menyajikan rata-rata konsumsi energi dan protein per kapita per hari pada rumah tangga miskin responden di kedua lokasi penelitian. Berdasarkan Tingkat Kecukupan Energi (TKE) maka rumah tangga miskin responden di kedua lokasi penelitian tergolong defisit ringan (80-90\% kecukupan). Bila ditinjau pada masing-masing kelurahan, tingkat kecukupan energi pada rumah tangga miskin di Kelurahan Kedung Jaya tergolong defisit ringan (8090\% kecukupan) dan di Kelurahan Tajur tergolong defisit sedang (70-80\% kecukupan). Sementara itu, berdasarkan tingkat kecukupan protein dapat diketahui bahwa rumah tangga miskin responden di Kelurahan Kedung Jaya tergolong normal 
(>90\% kecukupan). Namun, di Kelurahan Tajur tingkat kecukupan protein rumah tangga miskin responden masih tergolong pada defisiensi ringan (80-90\% kecukupan). Kondisi tersebut mengindikasikan bahwa tingkat kecukupan energi dan protein pada rumah tangga miskin di Kelurahan Kedung Jaya masih lebih baik daripada di Kelurahan Tajur.

Tabel 2. Kondisi pengeluaran tunai rumah tangga miskin responden

\begin{tabular}{|c|c|c|c|c|c|}
\hline \multirow[t]{2}{*}{ Kelurahan } & \multirow{2}{*}{$\begin{array}{l}\text { Rata-rata } \\
\text { pengeluaran } \\
\text { rumah } \\
\text { tangga/kapita/ } \\
\text { bulan (Rp) }\end{array}$} & \multirow{2}{*}{$\begin{array}{c}\text { Rata-rata } \\
\text { pengeluaran } \\
\text { pangan rumah } \\
\text { tangga/kapita/ } \\
\text { bulan (Rp) }\end{array}$} & \multicolumn{3}{|c|}{$\begin{array}{c}\text { Rata-rata persentase } \\
\text { pengeluaran rumah tangga/ } \\
\text { bulan }\end{array}$} \\
\hline & & & $\begin{array}{l}\text { untuk } \\
\text { pangan } \\
(\%)\end{array}$ & $\begin{array}{c}\text { untuk } \\
\text { beras } \\
(\%)\end{array}$ & $\begin{array}{c}\text { untuk } \\
\text { minyak } \\
\text { tanah } \\
(\%)\end{array}$ \\
\hline Kedung & $115310.79 \pm$ & $67813.20 \pm$ & 60.07 & 22.66 & 14.45 \\
\hline Jaya & 50389.82 & 30747.17 & & & \\
\hline Tajur & $\begin{array}{c}132898.16 \pm \\
43361.38\end{array}$ & $\begin{array}{c}74883.22 \pm \\
22480.13\end{array}$ & 58.03 & 22.65 & 16.82 \\
\hline TOTAL & $\begin{array}{c}12338368 \pm \\
47732.47\end{array}$ & $\begin{array}{c}71058.46 \pm \\
27280.70\end{array}$ & 59.13 & 22.66 & 15.54 \\
\hline
\end{tabular}

Sumber : data primer (diolah) 2006.

Pada Tabel 3 juga terlihat bahwa di Kelurahan Kedung Jaya, rata-rata konsumsi per kapita per hari rumah tangga miskin adalah $1684.06 \pm 672.49$ kkal energi dan 38.93 \pm 15.90 gram protein. Sementara itu, di Kelurahan Tajur rata-rata konsumsi energi rumah tangga miskin per kapita per hari lebih rendah dari Kelurahan Kedung Jaya, yaitu $1520.55 \pm 608.32 \mathrm{kkal}$, namun rata-rata konsumsi protein per kapita per hari nya lebih tinggi dari Kelurahan Kedung Jaya, yaitu $45.48 \pm 21.93$ gram.

Tabel 3. Rata-rata konsumsi dan tingkat kecukupan energi dan protein rumah tangga miskin responden

\begin{tabular}{lcccc}
\hline \multirow{2}{*}{ Kelurahan } & \multicolumn{2}{c}{ Rata-rata konsumsi per kapita per hari } & \multicolumn{2}{c}{ Tingkat kecukupan } \\
\cline { 2 - 5 } & \multicolumn{1}{c}{$\begin{array}{c}\text { Energi } \\
(\mathbf{k k a l} / \mathbf{k a p} / \mathbf{h a r i})\end{array}$} & $\begin{array}{c}\text { Protein } \\
(\text { gr/kap/hari) }\end{array}$ & $\begin{array}{c}\text { Energi } \\
(\% \text { AKE) }\end{array}$ & $\begin{array}{c}\text { Protein } \\
(\% \mathbf{A K P})\end{array}$ \\
\hline Kedung Jaya & $1684.06 \pm 672.49$ & $38.93 \pm 15.90$ & 84.80 & 98.88 \\
Tajur & $1520.55 \pm 608.32$ & $45.48 \pm 21.93$ & 77.99 & 88.10 \\
TOTAL & $1609.00 \pm 643.80$ & $41.93 \pm 19.03$ & 81.67 & 93.93 \\
\hline
\end{tabular}

Sumber : data primer (diolah) 2006. 
Berdasarkan data Susenas tahun 2002, Atmarita \& Fallah (2004) menunjukkan bahwa konsumsi energi di wilayah perkotaan adalah $1954 \mathrm{kkal} / \mathrm{kapita} / \mathrm{hari}$ (dengan tingkat kecukupan energi 88.8\%) dan konsumsi proteinnya adalah 55.9 gram/kapita/hari (dengan tingkat kecukupan protein 116.7\%). Hasil penelitian ini, seperti yang tersaji pada Tabel 3, menunjukkan bahwa di kedua lokasi penelitian mempunyai konsumsi dan tingkat kecukupan energi dan protein yang lebih rendah. Hal ini dapat dijelaskan karena rumah tangga yang dijadikan responden dalam penelitian ini merupakan rumah tangga miskin. Keadaan tersebut menegaskan adanya ancaman ketidaktahanan pangan pada rumah tangga miskin di kedua lokasi penelitian. Tabel 4 berikut ini disajikan konsumsi energi/kapita/hari rumah tangga miskin responden berdasarkan golongan pengeluaran untuk pangan.

Tabel 4. Rata-rata konsumsi energi dan protein/kapita/hari rumah tangga miskin responden menurut golongan pengeluaran untuk pangan

\begin{tabular}{ccccc}
\hline $\begin{array}{c}\text { Golongan pengeluaran untuk pangan } \\
(\mathbf{R p} / \mathbf{k a p} / \mathbf{b l})\end{array}$ & \multicolumn{2}{c}{$\begin{array}{c}\text { Rata-rata } \\
\text { konsumsi/kap/hr }\end{array}$} & \multicolumn{2}{c}{ Kecukupan (\%) } \\
& $\begin{array}{c}\text { Energi } \\
\text { (kkal) }\end{array}$ & $\begin{array}{c}\text { Protein } \\
(\mathbf{g r})\end{array}$ & Energi & Protein \\
& 1219.86 & 29.46 & 55.41 & 58.92 \\
\hline 40000.00 & 1505.77 & 33.86 & 68.44 & 67.72 \\
$40000.00-59999.00$ & 1662.62 & 48.43 & 75.57 & 96.86 \\
$60000.00-79999.00$ & 1387.05 & 38.61 & 63.05 & 77.22 \\
$80000.00-99999.00$ & 2166.33 & 54.87 & 98.47 & 109.74 \\
$100000.00-149999.00$ & 2451.32 & 55.02 & 111.42 & 110.04 \\
\hline $150000.00-199999.00$ & & & \\
\hline
\end{tabular}

Keterangan : ${ }^{*}$ Standar kecukupan energi $=2200$ kkal, standar kecukupan protein $=$ $50 \mathrm{gr}$

Sumber : data primer (diolah) 2006.

Suryana (2004), berdasarkan data Susenas tahun 2003, menyebutkan bahwa dengan standar kecukupan energi $2200 \mathrm{kkal}$ dan protein 50 gr per kapita per hari, sebagian besar masyarakat masih mengalami defisit energi dan protein ( $<90 \%$ kecukupan). Berdasarkan standar kecukupan tesebut, pada tahun 2003 disebutkan bahwa masyarakat yang masih mengalami defisit energi tersebar pada kelompok pengeluaran untuk pangan per kapita per bulannya antara Rp 40 000.00-Rp 59 999.00 hingga kelompok Rp 150 000.00-Rp 199 999.00, dengan konsumsi energi antara 1322 hingga 1998 kalori/kapita/hari yang mencapai 127.9 juta jiwa atau sekitar $60 \%$ dari seluruh penduduk Indonesia. Semenetara itu, defisit protein terjadi pada masyarakat dengan pengeluaran untuk pangan antara $\mathrm{Rp} 40$ 000.00-Rp 59 999.00 sampai dengan kelompok Rp 80 000.00-Rp 99 999.00, dengan konsumsi protein antara 32.6 hingga 41.3 gram yang mencapai 23.76 juta jiwa atau sekitar $11.15 \%$ dari seluruh penduduk Indonesia.

Hasil penelitian ini, dengan merujuk pada Suryana (2004) yang merupakan penilaian secara nasional, menunjukkan kondisi yang sedikit berbeda. Hasil penelitian ini menunjukkan bahwa rumah tangga miskin responden hanya mempunyai enam kelompok pengeluaran untuk pangan (dari sembilan kelompok yang ada dalam Suryana 2004) dan rumah tangga miskin responden yang pengeluaran untuk pangan 
berada dalam kelompok Rp 100 000.00-Rp 149999.00 dan Rp 150 000.00-Rp 199 999.00 ternyata tidak mengalami defisit energi maupun protein. Saat penelitian dilakukan harga beras di sekitar warung rumah tangga miskin responden berada dalam kisaran Rp 3 500.00/kg, sehingga rumah tangga miskin responden dengan kelompok pengeluaran untuk pangannya antara $\mathrm{Rp} 100 \quad 000.00-\mathrm{Rp} \quad 149$ 999.00/kapita/bulan akan setara dengan 28.57-42.87 kg/beras/kapita/bulan. Menurut Sajogya, "ambang kecukupan" untuk daerah perkotaan adalah 30-40 kg nilai tukar beras/orang/bulan (Mantra 1996). Hal tersebut mencerminkan bahwa terdapat beberapa rumah tangga dalam kelompok pengeluaran untuk pangan Rp 100000.00 Rp 149 999.00/kapita/bulan yang tetap terpenuhi kecukupan energi dan protein meskipun sebenarnya mereka di bawah "ambang kecukupan". Kondisi ini mengindikasikan bahwa terdapat mekanisme lain selain pembelian pangan yang bekerja dalam lingkungan rumah tangga miskin sehingga rumah tangga miskin responden tetap dapat tercukupi kebutuhan energi dan proteinnya.

Sementara itu, berdasarkan Tingkat Kecukupan Energi di setiap rumah tangga responden terlihat bahwa jumlah rumah tangga miskin yang tahan pangan di Kelurahan Kedung Jaya masih lebih banyak daripada di Kelurahan Tajur (Tabel 5). Oleh karenanya, bisa disimpulkan bahwa secara umum kondisi ketahanan pangan rumah tangga miskin di Kelurahan Kedung Jaya lebih baik daripada di Kelurahan Tajur. Meskipun begitu, tingkat ketahanan pangan rumah tangga miskin di kedua lokasi penelitian masih lebih baik dari tingkat ketahanan pangan rumah tangga di Kelurahan Mulyaharja, Kecamatan Bogor Selatan, Kota Bogor. Di Kelurahan Mulyaharja, terdapat $26.5 \%$ rumah tangga rawan pangan dan $62.9 \%$ rumah tangga sangat rawan pangan atau terdapat $81.4 \%$ rumah tangga yang tidak tahan pangan (Masithoh 2002).

Tabel 5. Ketahanan pangan rumah tangga miskin responden berdasarkan Tingkat Kecukupan Energi rumah tangga

\begin{tabular}{llcc}
\hline Kelurahan & \multicolumn{2}{c}{$\begin{array}{c}\text { Ketahanan pangan rumah tangga berdasarkan Tingkat } \\
\text { Kecukupan Energi rumah tangga }\end{array}$} \\
\cline { 2 - 4 } & & Tidak tahan & Tahan \\
\hline Kedung & $\mathrm{n}$ & 21 & 12 \\
Jaya & $\%$ & 63.6 & 36.4 \\
\hline Tajur & $\mathrm{n}$ & 19 & 9 \\
& $\%$ & 67.9 & 32.1 \\
\hline TOTAL & $\mathrm{n}$ & 40 & 21 \\
& $\%$ & 65.6 & 34.4 \\
\hline
\end{tabular}

Sumber : data primer (diolah) 2006.

Selanjutnya, berdasarkan pengeluaran per kapita per bulan rumah tangga responden (Tabel 6), menunjukkan bahwa jumlah rumah tangga miskin yang mempunyai ketahanan pangan rumah tangga terbanyak di Kelurahan Kedung Jaya adalah rumah tangga miskin dengan tingkat pengeluaran per kapita per bulan di atas Rp 150 $000.00(21.2 \%)$. Sementara itu, di lokasi yang sama jumlah rumah tangga miskin responden terbanyak yang berada dalam kondisi tidak tahan pangan adalah rumah tangga miskin dengan tingkat pengeluaran per kapita per bulan di bawah Rp 86 
500.00 (27.3\%). Kondisi tersebut merupakan keragaan yang ideal, yang mana dapat dijelaskan karena semakin besar pengeluaran rumah tangga per kapita per bulan maka mengindikasikan semakin baiknya kemampuan ekonomi suatu rumah tangga. Kondisi rumah tangga yang semakin baik kemampuan ekonominya akan menyebabkan pemenuhan kebutuhan pangan yang bergizi dan sesuai norma gizi pun juga semakin baik sehingga kecenderungannya akan menyebabkan rumah tangga semakin tahan pangan.

Tabel 6 juga menunjukkan keragaan yang berbeda di Kelurahan Tajur, yang mana persentase terbanyak rumah tangga miskin responden yang tahan pangan $(17.9 \%)$ adalah rumah tangga yang tingkat pengeluaran per kapita per bulannya berada dalam kelompok Rp 86500.00 s.d < Rp 126 000.00. Sementara itu, rumah tangga miskin yang tidak tahan pangan juga mempunyai keragaan yang berbeda dengan Kelurahan Kedung Jaya, yang mana persentase terbanyak rumah tangga miskin responden yang tidak tahan pangan $(32.1 \%)$ di Kelurahan Tajur adalah rumah tangga yang tingkat pengeluaran per kapita per bulannya berada dalam kelompok Rp 126000.00 s.d. $\leq$ Rp 150000.00 .

Tabel 6. Sebaran rumah tangga miskin responden berdasarkan ketahanan pangan dan pengeluaran rumah tangga per kapita per bulan

\begin{tabular}{|c|c|c|c|c|}
\hline- & Ketahanan pangan & & $\begin{array}{r}\text { Ketahanan } \\
\text { ta }\end{array}$ & rumah \\
\hline per kapi & per bulan (Rp) & & Fidak tahan & Tahan \\
\hline Kedung & $<\mathrm{Rp} 86.500,00$ & $\mathrm{n}$ & 9 & 2 \\
\hline Jaya & & $\%$ & 27.3 & 6.1 \\
\hline & $\operatorname{Rp} 86.500,00-<\operatorname{Rp} 126.000,00$ & $\mathrm{n}$ & 6 & 1 \\
\hline & & $\%$ & 18.2 & 3.0 \\
\hline & Rp $126.000,00-\leq \operatorname{Rp} 150.000,00$ & $\mathrm{n}$ & 5 & 2 \\
\hline & & $\%$ & 15.2 & 6.1 \\
\hline & $>\operatorname{Rp} 150.000,00$ & $\mathrm{n}$ & 1 & 7 \\
\hline & & $\%$ & 3.0 & 21.2 \\
\hline Tajur & $<\mathrm{Rp} \mathrm{86.500,00}$ & $\mathrm{n}$ & 3 & 1 \\
\hline & & $\%$ & 10.7 & 3.6 \\
\hline & $\operatorname{Rp} 86.500,00-<\operatorname{Rp} 126.000,00$ & $\mathrm{n}$ & 3 & 5 \\
\hline & & $\%$ & 10.7 & 17.9 \\
\hline & Rp $126.000,00-\leq \operatorname{Rp} 150.000,00$ & $\mathrm{n}$ & 9 & 0 \\
\hline & & $\%$ & 32.1 & 0.0 \\
\hline & $>\operatorname{Rp} 150.000,00$ & $\mathrm{n}$ & 4 & 3 \\
\hline & & $\%$ & 14.3 & 10.7 \\
\hline
\end{tabular}

Sumber : data primer (diolah) 2006.

Lebih lanjut, uji korelasi Spearman antara ketahanan pangan rumah tangga dengan pengeluaran rumah tangga per kapita per bulan menghasilkan koefisien korelasi sebesar $0.259^{*}$. Koefisien ini menunjukkan bahwa pada level $\alpha=0.05$ terdapat hubungan yang signifikan antara ketahanan pangan rumah tangga dengan pengeluaran rumah tangga per kapita per bulan. Apabila semakin tinggi pengeluaran rumah tangga per kapita per bulan menunjukkan semakin baik kemampuan ekonomi 
suatu rumah tangga, maka hasil tersebut menegaskan bahwa ketahanan pangan rumah tangga yang lebih baik akan dimiliki oleh rumah tangga-rumah tangga yang kemampuan ekonominya lebih baik. Hal ini menegaskan bahwa salah satu faktor yang menentukan dalam menciptakan ketahanan pangan rumah tangga miskin khususnya di daerah perkotaan adalah aksesibilitas ekonomi rumah tangga terhadap pangan, dalam hal ini daya beli rumah tangga yang ditentukan oleh pendapatan yang dimiliki rumah tangga. Namun, kondisi tersebut menjadi sangat rawan apabila besarnya pengeluaran per kapita rumah tangga tidak diikuti dengan meningkatnya pendapatan per kapita rumah tangga. Oleh karena itu, apabila pendapatan rumah tangga tetap stabil atau bahkan menurun ditambah dengan harga kebutuhan pangan yang cenderung terus naik, kemungkinan terjadinya ketidaktahanan pangan rumah tangga miskin perkotaan akan menjadi lebih besar. Hal ini menegaskan bahwa kemampuan ekonomi rumah tangga memegang peranan penting dalam menciptakan ketahanan pangan rumah tangga miskin perkotaan.

Meskipun kemampuan ekonomi merupakan faktor yang cukup penting dalam mewujudkan ketahanan pangan rumah tangga, Tabel 6 juga menunjukkan keragaan keragaan yang unik (anomali) di Kelurahan Tajur, yang mana kelompok rumah tangga miskin yang mempunyai tingkat pengeluaran per kapita per bulan lebih tinggi justru mempunyai kecenderungan menjadi tidak tahan pangan. Sebaliknya, sebagian besar rumah tangga yang tingkat pengeluarannya lebih rendah justru mempunyai kondisi yang tahan pangan. Kondisi tersebut mengindikasikan bahwa selain kekuatan ekonomi yang bekerja dalam menentukan ketahanan pangan rumah tangga miskin di lokasi penelitian, terdapat potensi-potensi di luar kemampuan ekonomi rumah tangga yang membantu rumah tangga tetap tahan pangan. Potensi-potensi di luar kemampuan ekonomi tersebut menunjuk pada potensi yang tidak berbentuk uang namun secara ekonomi bermanfaat dalam membantu rumah tangga tetap tahan pangan meskipun kemampuan ekonominya rendah. Salah satunya adalah potensi yang ada dalam hubungan sosial antar rumah tangga miskin di kedua lokasi penelitian. Potensi tersebut adalah dalam bentuk modal sosial. Penelitian ini menunjukkan bahwa rumah tangga yang tahan pangan adalah rumah tangga yang mempunyai modal sosial berupa kepercayaan yang lebih tinggi dalam menjalin hubungan tanpa rasa saling curiga, kepercayaan yang lebih tinggi dalam menjaga lingkungan tetap langgeng (sustain), hubungan sosialnya lebih banyak dalam pemenuhan kebutuhan pangan rumah tangganya, dan istri bukan penduduk asli lingkungan tempat tinggal. Secara rinci, potensi modal sosial dalam membantu menguatkan ketahanan pangan rumah tangga miskin di kedua lokasi penelitian akan dibahas pada bab berikutnya.

\section{ANALISIS KETAHANAN PANGAN BERBASIS MODAL SOSIAL DI LOKASI PENELITIAN}

Dalam penelitian ini, konsep modal sosial dijelaskan dengan tiga komponen utama seperti yang dikonseptualisasi oleh Putnam yaitu kepercayaan (trust), jaringan sosial (social networks), dan norma sosial (social norms). Pembahasan modal sosial pada tulisan ini dikhususkan dalam kerangka ketahanan pangan pada rumah tangga miskin responden penelitian. Modal sosial dapat dipandang sebagai sumberdaya baik yang potensial maupun aktual yang timbul dari adanya hubungan-hubungan sosial, 
sehingga pada tulisan ini akan dibahas terlebih dahulu hubungan-hubungan sosial yang terbangun pada rumah tangga miskin perkotaan di lokasi penelitian.

\section{Hubungan Sosial}

Hasil penelitian ini menunjukkan bahwa hubungan sosial yang dimiliki rumah tangga miskin responden dengan rumah tangga lain dalam komunitasnya di kedua lokasi penelitian merupakan hubungan yang basisnya adalah hubungan pertetanggaan. Namun ada basis lain yaitu kekerabatan (keluarga luas) yang disebabkan oleh letak tempat tinggal rumah tangga miskin responden dengan saudara mereka saling berdekatan (Gambar 1). Landasan hubungan kekerabatan dalam komunitas di kedua lokasi penelitian dapat dijelaskan karena 93.1\% rumah tangga miskin responden, suami atau istri atau keduanya berasal dari lingkungan dimana mereka menetap saat ini. Hal ini menyebabkan letak rumah saudara dan kerabat responden saling berdekatan.

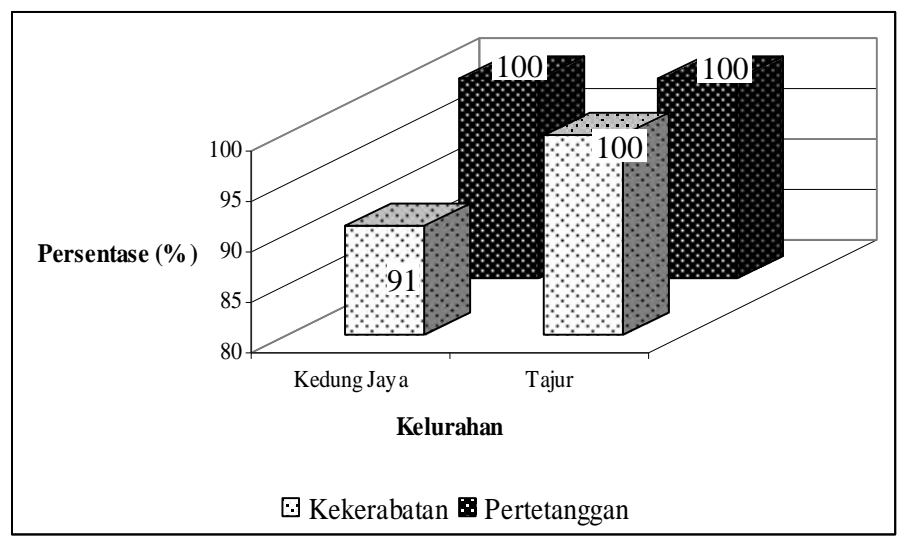

\section{Gambar 1 Sebaran basis hubungan sosial rumah tangga miskin responden dengan rumah tangga lain di lingkungan tempat tinggal}

Sumber : data primer (diolah) 2006.

Basis pertetanggaan memegang peranan penting dalam hubungan sosial antar rumah tangga miskin responden, seperti yang diungkapkan Ibu Rhm (58 th), bahwa menjaga hubungan sosial yang baik dengan tetangga merupakan investasi sosial bagi rumah tangga tersebut. Suatu saat bila ada anggota rumah tangga yang kesulitan, maka harapannya tetangga akan melakukan kebaikan yang sama seperti yang pernah dilakukannya.

"Ibu sudah lama tinggal di sini, jadi sudah banyak kenal tetangga di sini. Dengan tetangga harus menjaga hubungan baik, karena mungkin suatu saat anak ibu di perantauan membutuhkan pertolongan. Kalau Ibu berbuat baik dengan tetangga, anak ibu yang di rantau juga akan dibantu oleh tetangganya. Jadi penting mempunyai hubungan baik dengan tentangga kita” (Ibu Rhm, 58 th) .

Membangun hubungan dalam komunitas dengan motivasi seperti yang disampaikan oleh Ibu Rhm (58 th), menegaskan apa yang disampaikan oleh James Coleman bahwa modal sosial mencakup adanya sekumpulan harapan dan kewajiban 
(expectations and obligations) yang muncul dalam sebuah hubungan sosial yang terjalin (Winter 2000). Dalam kasus Ibu Rhm (58 th) terlihat jelas bahwa Ibu Rhm (58 th) mempunyai harapan bahwa kebaikan yang dia "tanam" kepada tetangganya akan dapat "dituai" bukan saja oleh dirinya, namun juga oleh anaknya. Hal ini menunjukkan bahwa investasi modal sosial dapat dipetik hasilnya secara lintas generasi. Kondisi tersebut menunjukkan mekanisme modal sosial bekerja dalam hubungan antar rumah tangga di lokasi penelitian melalui nilai-nilai harapan dan kewajiban (expectations and obligations) antar rumah tangga yang berinteraksi. Selain basis pertetanggaan, basis kekerabatan juga memegang peranan penting dalam hubungan sosial antar rumah tangga miskin di lokasi penelitian (Kasus Ibu Ndn, 23 th). Hal ini memperkuat pendapat Warren et al. (2001) bahwa orang miskin sangat tergantung pada dukungan keluarga luasnya (kerabat) untuk dapat bertahan hidup.

"Tetangga-tetangga dekat di sini semua adalah saudara. Sederetan rumah saya ini, semuanya adalah saudara suami saya. Beruntung juga punya tetangga saudara sendiri, kalau ada apa-apa minta tolongnya dekat. Anak juga jadi lebih dekat dengan saudara-saudaranya. Jadi mengawasinya juga tidak susah, karena bermainnya dengan saudaranya sendiri atau main di rumah saudara di sebelah" (Ibu Ndn, 23 th) .

Sementara itu, hubungan sosial rumah tangga miskin responden dengan orang lain di luar komunitasnya dapat berlangsung sebatas adanya hubungan kekerabatan dan pertemanan. Hasil penelitian ini menunjukkan bahwa $27.9 \%$ rumah tangga miskin responden mempunyai hubungan sosial dengan luar komunitasnya karena adanya hubungan kekerabatan dan $72.1 \%$ rumah tangga mempunyai hubungan sosial dengan luar komunitasnya karena adanya hubungan pertemanan. Keragaan tersebut menunjukkan bahwa pihak di luar komunitas yang sering berinteraksi dengan rumah tangga miskin di kedua lokasi penelitian adalah kerabat (keluarga luas) dan teman.

Bentuk jaringan sosial yang mengandalkan basis non-genealogis dan dasar ikatan organisasional jelas tidak terbentuk pada komunitas miskin perkotaan di lokasi penelitian. Modal sosial terbentuk dalam format yang sangat sederhana yang mana basis hubungan kekerabatan dan pertetanggaan di lingkungan tempat tinggal serta basis kekerabatan dan pertemanan dalam hubungan sosial dengan luar komunitas dilandasi oleh kepercayaan yang timbul dari kedekatan hubungan sosial yang terjalin sejak lama. Hal ini merupakan potensi modal sosial satu-satunya yang dimiliki, yaitu ketika mereka sudah percaya dan merasa dekat dengan kerabat ataupun tetangganya, mereka merasa nyaman untuk saling membantu.

\section{Modal Sosial dan Ketahanan Pangan Rumah Tangga Miskin}

Martin et al. (2004) dalam penelitiannya tentang hubungan modal sosial dan penurunan resiko kelaparan pada rumah tangga berpendapatan rendah di Connecticut, Amerika Serikat menunjukkan bahwa modal sosial yang diukur dengan kepercayaan, hubungan timbal balik, dan jaringan sosial pada tingkat rumah tangga dan komunitas berhubungan signifikan terhadap ketahanan pangan rumah tangga. Selain itu, penelitian tersebut juga menemukan bahwa modal sosial pada tingkat komunitas berhubungan signifikan dengan penurunan resiko kelaparan pada rumah tangga miskin berpendapatan rendah. Berdasarkan penghitungan indeks modal sosial 
dengan mekanisme seperti yang telah disajikan dalam Metodologi Penelitian dalam tulisan ini, berikut disajikan mengenai keragaan ketahanan pangan rumah tangga miskin responden di kedua lokasi penelitian berdasarkan ketiga komponen modal sosial tersebut (Gambar 2).

Hasil penelitian ini juga menunjukkan kecenderungan yang sama dengan hasil penelitian Martin et al. (2004), yaitu rumah tangga miskin responden dengan tingkat kepercayaan (trust), jaringan sosial (social networks), dan norma sosial (social norms) yang rendah maka akan cenderung berada dalam kondisi tidak tahan pangan. Sebaliknya, apabila rumah tangga mempunyai tingkat kepercayaan tinggi maka akan cenderung berada dalam kondisi tahan pangan, seperti yang terlihat di Kelurahan Kedung Jaya (Gambar 2). Gambar 2 menunjukkan bahwa modal sosial mempunyai potensi dalam mewujudkan rumah tangga miskin yang tahan pangan. Kondisi tersebut mengindikasikan bahwa "berkah" modal sosial (social capital endowment) yang tinggi dalam komunitas rumah tangga miskin, khususnya yang tinggal di daerah perkotaan, dapat berguna untuk meningkatkan ketahanan pangan rumah tangga miskin. Hal inilah yang kemungkinan dapat menjelaskan fenomena yang diuraikan pada bab mengenai ketahanan pangan rumah tangga miskin di lokasi penelitian dalam tulisan ini, yang mana meskipun dihadapkan pada persoalan kemampuan ekonomi rumah tangga yang lebih rendah namun rumah tangga miskin dapat memelihara ketahanan pangan yang cukup baik. Gambar 2 juga menunjukkan bahwa Kelurahan Kedung Jaya mempunyai tingkat modal sosial yang lebih baik daripada Kelurahan Tajur. Hal ini terlihat dari tidak adanya tingkat kepercayaan (trust), jaringan sosial (social networks), dan norma sosial (social norms) rumah tangga miskin responden di Kelurahan Tajur yang masuk dalam kategori tinggi. Kondisi inilah yang kemudian dapat menjelaskan bahwa stok modal sosial yang lebih tinggi pada rumah tangga miskin bertanggung jawab dalam mewujudkan ketahanan pangan rumah tangga yang lebih baik di Kelurahan Kedung Jaya. Kondisi tersebut mempertegas penelitian Martin et al. (2004) bahwa modal sosial yang dibangun dari kepercayaan, jaringan sosial, dan norma sosial pada rumah tangga miskin mempunyai potensi dalam menungkatkan kondisi ketahanan pangan rumah tangga miskin.

\section{Mekanisme Modal Sosial dalam Penguatan Ketahanan Pangan Rumah Tangga}

Kepercayaan (Trust). Mollering menyebutkan bahwa modal sosial mempunyai enam fungsi penting yaitu : (1) kepercayaan dalam arti confidence yang merupakan ranah psikologis individual sebagai sikap yang akan mendorong seseorang dalam mengambil keputusan setelah menimbang resiko yang akan diterima; (2) kerja sama yang menempatkan trust sebagai dasar hubungan antar individu tanpa rasa saling curiga; (3) penyederhanaan pekerjaan yang memfungsikan trust sebagai sumber untuk membantu meningkatkan efisiensi dan efektivitas kerja kelembagaankelembagaan sosial; (4) ketertiban dimana trust sebagai inducing behaviour setiap individu untuk menciptakan kedamaian dan meredam kekacauan sosial; (5) pemelihara kohesivitas sosial yang membantu merekatkan setiap komponen sosial yang hidup dalam komunitas menjadi kesatuan; (6) trust sebagai modal sosial yang menjamin struktur sosial berdiri secara utuh dan berfungsi secara operasional serta efisien (Dharmawan 2002a; 2002b). Penelitian ini menggunakan keenam ranah fungsi kepercayaan (trust) sebagai salah satu ukuran modal sosial. 
Kepercayaan

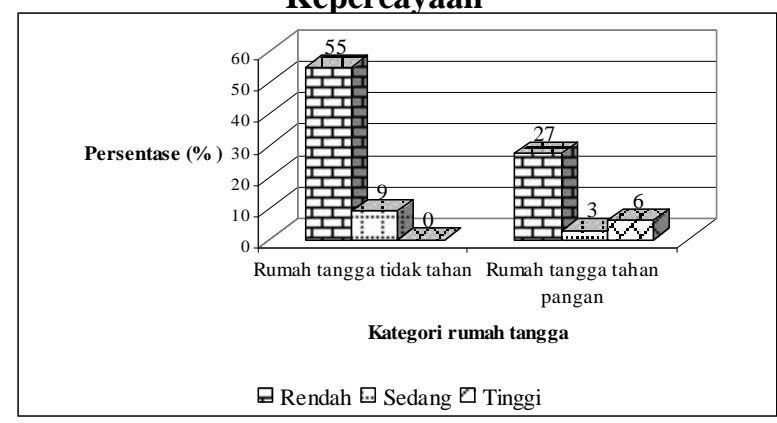

Jaringan Sosial

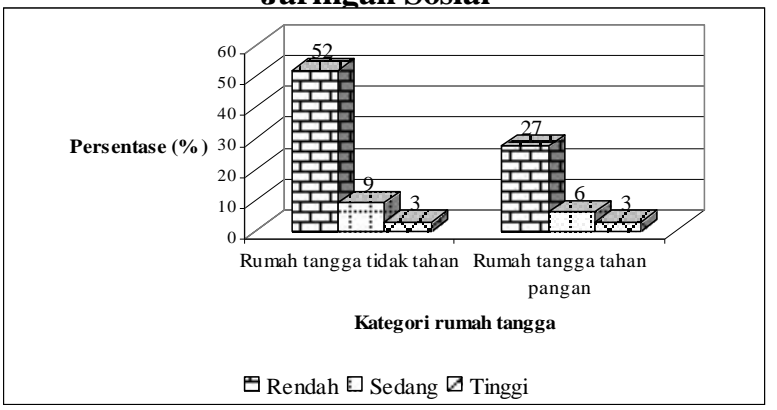

Norma Sosial

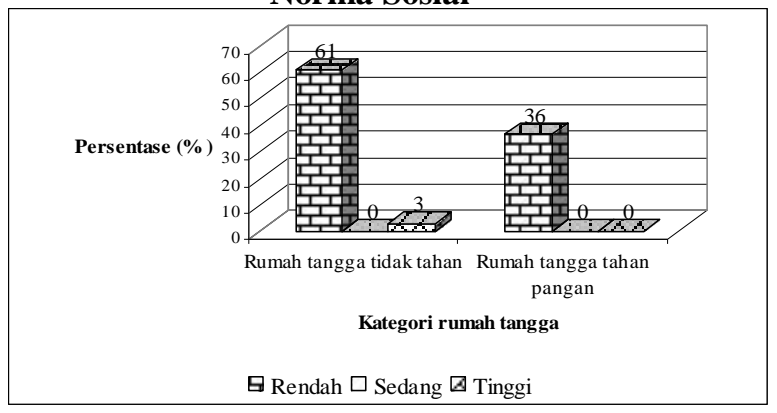

Kelurahan Kedung Jaya
Kepercayaan

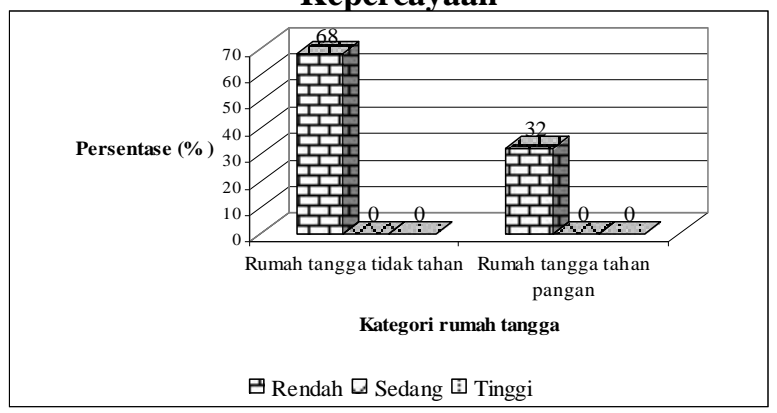

Jaringan Sosial

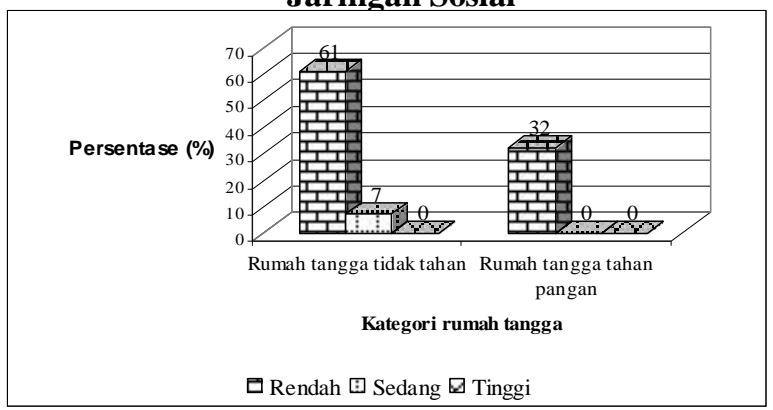

Norma Sosial

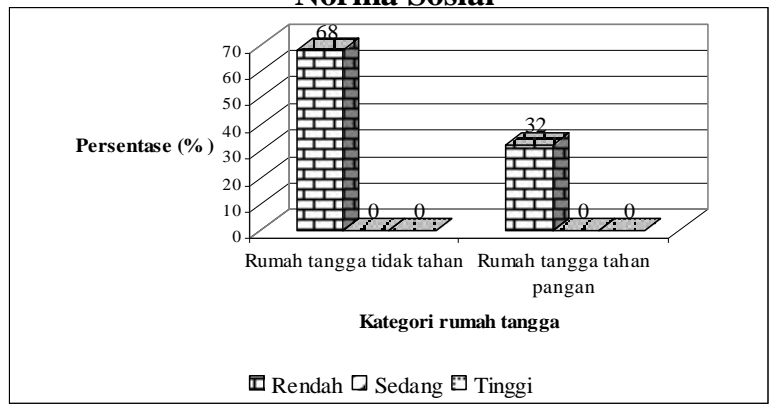

Kelurahan Tajur

\section{Gambar 2 Keragaan ketahanan pangan rumah tangga miskin responden berdasarkan indeks modal sosial}

Sumber : data primer (diolah) 2006.

Uji korelasi Spearman menunjukkan bahwa komponen kepercayaan yang mempunyai hubungan signifikan dengan ketahanan pangan rumah tangga miskin adalah kepercayaan diri rumah tangga untuk menjalin kerjasama tanpa rasa saling curiga (koefisien Spearman $=0.392$, signifikan pada $\alpha=0.01$ ) dan kepercayaan rumah tangga bahwa lingkungannya dapat menjaga hubungan di antara mereka tetap sustain (koefisien Spearman $=0.315$, signifikan pada $\alpha=0.05$ ). Hasil uji korelasi ini menunjukkan bahwa semakin tinggi kepercayaan untuk menjalin kerjasama tanpa rasa saling curiga dan juga semakin tinggi kepercayaan bahwa rumah tangga dan lingkungannya dapat menjaga hubungan di lingkungan tempat tinggalnya tetap 
sustain, maka semakin tinggi tingkat ketahanan pangan rumah tangga miskin. Kecenderungan ini bisa dijelaskan dengan analisis bahwa agar rumah tangga miskin dan lingkungannya dapat sustain (sistem sosialnya berjalan langgeng) maka mereka harus meningkatkan kerjasama (tolong menolong) diantara mereka tanpa rasa saling curiga. Hal ini seperti yang diungkapkan Bp Rtj (55 th), bahwa di lingkungannya hubungan antar rumah tangga cukup dekat dan dapat saling membantu tanpa rasa saling curiga dan hal ini bermanfaat dalam membantu kesulitan yang dihadapi rumah tangga di lingkungannya. Sehingga bila ada kasus tetangganya tidak mempunyai sumberdaya untuk mengakses pangan secara cukup maka komunitas itu akan saling membantu agar rumah tangga di dalam komunitas dapat memenuhi kebutuhan pangannya dengan baik. Hal ini menguatkan pendapat Warren et al. (2001) bahwa modal sosial bukanlah sebagai alternatif untuk menyediakan sumberdaya finansial yang lebih besar bagi masyarakat miskin, namun yang lebih penting adalah meningkatkan kemampuan sumberdaya yang ada sehingga lebih efektif digunakan.

Sifat Jaringan Sosial. Hasil penelitian ini menunjukkan bahwa semua rumah tangga miskin responden mengaku mempunyai jaringan sosial yang bersifat informal, baik dalam hal hubungan sosial keseharian maupun dalam hubungan sosial dalam pemenuhan kebutuhan pangan. Kondisi ini dikarenakan ikatan pertetanggaan dan ikatan kekerabatan yang menjadi basis hubungan sosial rumah tangga miskin di kedua lokasi penelitian (Gambar 1). Sifat jaringan sosial informal yang terjalin di komunitas lokasi penelitian menunjukkan adanya hubungan sosial yang lebih lentur, yang terbangun oleh dorongan akan kebutuhan untuk menjalin hubungan sosial dengan orang lain. Kelenturan ini bila dipupuk secara baik maka hubungan sosial yang terjalin pun akan lebih menguat dan kemungkinan menjadi hubungan permanen yang lebih personal yang dapat berguna dalam mencapai tujuan bersama. Jaringan sosial informal tersebut mengindikasikan adanya kepercayaan dan hubungan timbal balik yang lebih familiar dan bersifat personal. Ikatan yang lebih familiar dan bersifat personal membuat hubungan-hubungan sosial antar rumah tangga menjadi lebih dekat. Sehingga hubungan-hubungan sosial tersebut dapat dimanfaatkan untuk mengeksplorasi upaya-upaya kolektif guna mengoptimalkan sumberdaya yang ada dalam rangka meningkatkan kesejahteraan anggota komunitasnya, dalam hal ini rumah tangga miskin.

Basis Jaringan Sosial. Seperti halnya basis hubungan sosial dalam keseharian rumah tangga miskin responden (Gambar 1), basis hubungan sosial rumah tangga miskin responden dengan rumah tangga lain di lingkungannya dalam rangka memenuhi kebutuhan pangannya sebagian besar juga dilandasi oleh hubungan kekerabatan $(32.8 \%)$ dan pertetanggaan (29.5\%). Gambar 3 menunjukkan bahwa kekerabatan dan pertetanggaan merupakan basis jaringan sosial (social networks) yang penting bagi rumah tangga miskin di Kelurahan Kedung Jaya untuk pemenuhan pangan. Sementara itu di Kelurahan Tajur, basis jaringan sosial yang lebih utama bagi rumah tangga miskin responden dalam pemenuhan pangan hanya kekerabatan saja. Apabila dibandingkan dengan Gambar 1, terlihat bahwa semua rumah tangga miskin responden di Kelurahan Tajur mempunyai hubungan kekerabatan dengan rumah tangga lain di lingkungan tempat tinggalnya, namun hanya $13.1 \%$ rumah tangga miskin responden yang memperoleh manfaat dari 
hubungan kekerabatan tersebut dalam pemenuhan pangannya (Gambar 3). Kondisi tersebut mencerminkan bahwa Kelurahan Kedung Jaya mempunyai basis modal sosial yang lebih baik, yang mana solidaritas pertetanggaan dan kekerabatan lebih terasa keberadaannya dalam rangka pemenuhan kebutuhan pangan rumah tangga miskin. Solidaritas pertetanggaan dan kekerabatan yang lebih hangat dan kuat inilah yang memberikan kontribusi terhadap ketahanan pangan rumah tangga miskin di Kelurahan Kedung Jaya. Penelitian ini menunjukkan bahwa meskipun secara ekonomi rata-rata pengeluaran rumah tangga miskin di Kelurahan Kedung Jaya lebih rendah yaitu Rp 115 310.79, namun jumlah rumah tangga miskin yang tahan pangan lebih banyak daripada di Kelurahan Tajur. Kondisi tersebut mengindikasikan bahwa basis modal sosial melalui hubungan kekerabatan dan juga pertetanggaan yang lebih kuat di Kelurahan Kedung Jaya berimplikasi terhadap lebih baiknya ketahanan pangan rumah tangga miskin di Kelurahan Kedung Jaya.

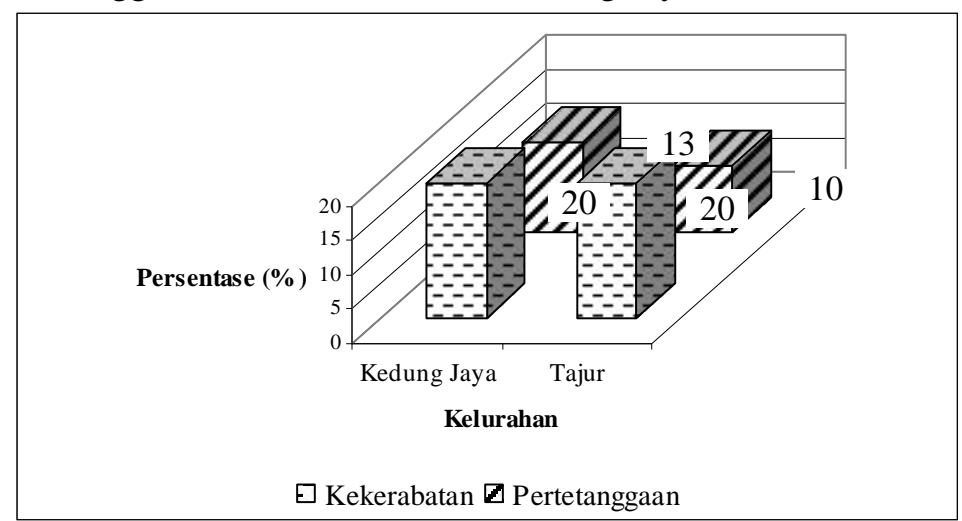

\section{Gambar 3 Basis hubungan sosial responden dalam pemenuhan kebutuhan pangan}

Sumber : data primer (diolah) 2006.

Dalam penelitian ini juga ditemukan bahwa terdapat satu responden di Kelurahan Kedung Jaya yang menjalin hubungan dengan rumah tangga lain dalam pemenuhan pangan atas dasar hubungan asal daerah yang sama (Ibu Tar, 75 th), dan responden tersebut merupakan salah satu rumah tangga miskin yang tahan pangan. Contoh kasus tersebut menunjukkan bahwa keterikatan asal daerah yang sama masih menjadi salah satu landasan hubungan sosial yang muncul di daerah perkotaan, khususnya di lokasi penelitian. Keterikatan ini dapat dikategorikan sebagai etika "bounded solidarity", yang mana solidaritas antar tetangga muncul karena merasa senasib sepenanggungan sebagai perantau (Woolcock 1998). Sebagai orang yang sama-sama merantau, nasib sepenanggungan menjadi pendorong untuk dapat saling tolong-menolong agar tetap bertahan hidup di perantauan.

Pada kasus hubungan sosial yang terjalin antara Ibu Tar dan Ibu Ay, sebenarnya Ibu Ay tidak mempunyai kemampuan finansial yang berlebih namun diakui Ibu Ay tentang adanya kebutuhan untuk saling menolong, apalagi sama-sama sebagai orang perantau. Hasilnya, hubungan sosial yang terjalin tersebut telah membantu rumah tangga Ibu Tar tetap dapat tahan pangan meskipun mempunyai kemampuan ekonomi yang terbatas. Kondisi tersebut menunjukkan salah satu 
bentuk konkret sumberdaya yang dimiliki dari suatu hubungan sosial di dalam komunitas yang pada kondisi tertentu dapat berubah menjadi modal ekonomi, seperti pendapat Pierre Bourdieu (Winter 2000).

"Emak sudah lama tinggal di sini, sudah lebih dari 20 tahun. Dulu di sini tinggalnya dengan suami, hanya saja sekarang suami sudah meninggal. Jadi sekarang tinggal berdua saja dengan menantu. Anak Emak yang menantunya tinggal di sini ada di kampung, di Bumiayu. Anak Emak lainnya tinggal di sini juga tapi berbeda rumah. Sehari-hari Emak bekerja sebagai tukang cuci, sebulan biasanya memperoleh 125 ribu. Tapi kalau sekarang itupun tidak pasti. Hasilnya biasanya habis untuk makan sehari-hari. Menantu Emak sehari-hari kerjanya narik becak. Dia punya tiga becak, yang dua ditarik orang lain. Tapi sekarang juga sedang rusak dua-duanya. Hasil narik becak juga tidak seberapa, sebulan sekali biasanya dia ngasih Emak 30 ribu buat tambah-tambah beli beras. Makan di rumah seadanya saja. Tapi Emak suka dikasih makanan oleh tetangga, oleh Ibu Ay. Dia sama-sama dari Bumiayu, dia juga punya becak. Kadang-kadang dia datang tiba-tiba, "Mak ini ada makanan", Alhamdulillah Neng, ada yang masih peduli" (Ibu Tar, 75 th).

Contoh kasus etika "bounded solidarity", yang dilandasi etika senasib sepenanggungan sebagai perantau, yang terbangun antara Ibu Tar dan Ibu Ay menunjukkan bahwa permasalahan ketahanan pangan pada rumah tangga miskin perantau yang tinggal di daerah perkotaan kadangkala masih bisa terbantu dengan adanya keterikatan senasib sepenanggungan sebagai orang rantau yang berasal dari daerah yang sama. Hanya saja, kondisi tersebut menjadi potensi munculnya permasalahan baru terkait dengan isu urbanisasi. Kasus tersebut menunjukkan bahwa bagi para perantau pelaku urbanisasi, keberanian mengadu nasib di kota salah satunya didorong oleh keyakinan akan perantau lain yang berasal dari daerah yang sama yang akan membantu bila dalam kesusahan. Salah satu contohnya adalah fenomena pedagang angkringan di Yogyakarta yang berasal dari luar Yogyakarta (Brata 2004). Pedagang angkringan di kota Yogyakarta yang berasal dari luar Yogyakarta (misalnya dari daerah Klaten) biasanya merupakan pedagang usianya yang relatif masih muda dan tergantung pada keberadaan juragan untuk menjamin suplai makanan yang dijual. Bagi mereka, informasi-informasi yang diperoleh dari teman sedesa ataupun kerabat, khususnya yang sudah terlebih dahulu menjadi pedagang angkringan, sangatlah penting artinya. Informasi dari teman sedesa ataupun kerabat itulah yang mengantarkan mereka untuk menjadi pedagang angkringan, termasuk sampai bertemu dengan juragan. Jaringan kekerabatan ataupun teman telah memberikan manfaat bagi mereka untuk memperoleh peluang usaha. Modal sosial berupa jaringan sosial di kampung halamannya telah membuka jalan baginya untuk memperoleh penghasilan lebih baik daripada tetap menjadi petani di desa asalnya. Kondisi tersebut dan juga hasil penelitian ini menunjukkan bahwa modal sosial berupa jaringan sosial di kampung halaman dan juga jaringan sosial ketika sudah berada di perantauan bagi para pelaku urbanisasi, memberi dampak terhadap terbukanya peluang usaha dan juga terbantunya kondisi ketahanan pangan rumah tangga para perantau. Etika "bounded solidarity” memegang peranan penting bagi para sesama perantau di daerah perantauan.

Kondisi tersebut tentu saja menempatkan modal sosial dalam dua sisi mata uang. Satu sisi, keberadaan modal sosial telah membantu para rumah tangga miskin 
perantau di perkotaan untuk tercukupi kebutuhan pangan, bahkan terbuka peluang usaha melalui jaringan sosial yang dimiliki dengan sesama perantau dari asal daerah yang sama. Namun di sisi lain, modal sosial berupa jaringan sosial yang dicirikan oleh etika "bounded solidarity" berpotensi terhadap meningkatnya arus urbanisasi. Urbanisasi akhirnya terus meningkat berkat adanya informasi kerabat atau teman sekampung/sedesa bahwa mengadu nasib di kota dapat diandalkan sebagai sumber penghasilan, seperti pada kasus pedagang angkringan di kota Yogyakarta yang berasal dari Klaten (Brata 2004). Kondisi tersebut menegaskan apa yang disebut Putzel sebagai dark side of sosial capital -sisi gelap modal sosial- (Winter 2000). Dark side of social capital tersebut menunjukkan bahwa jaringan sosial di kampung halaman dan juga jaringan sosial ketika sudah berada di perantauan bagi para pelaku urbanisasi, dapat menjelaskan mengapa urbanisasi terus meningkat dimana hubungan-hubungan sosial diantara para imigran sulit diceraikan begitu saja.

Seperti yang telah diuraikan sebelumnya bahwa variabel ketahanan pangan rumah tangga miskin perkotaan cukup sensitif terhadap pendapatan rumah tangga maka untuk menjamin rumah tangga dalam kondisi tahan pangan, rumah tangga miskin perkotaan harus mempunyai kemampuan pendapatan yang mencukupi. Artinya, usaha untuk meningkatkan pendapatan rumah tangga merupakan suatu kebutuhan bagi rumah tangga miskin perkotaan. Bila jaringan hanya terbatas pada kerabat, tetangga, ataupun teman yang sebagian besar kondisi ekonominya tidak jauh berbeda dengan rumah tangga miskin maka upaya untuk meningkatkan pendapatan akan terasa sulit. Sehingga jaringan tersebut perlu diperluas dengan pihak-pihak lain yang mampu membuka peluang bagi rumah tangga miskin untuk melakukan upaya alternatif guna meningkatkan kesejahteraannya.

Kedalaman Jaringan Sosial. Kedalaman jaringan dalam penelitian ini dilihat dari pengetahuan rumah tangga miskin responden terhadap kegiatan keseharian anggota rumah tangga lain di lingkungan tempat tinggalnya. Hasil penelitian ini menunjukkan bahwa $77.0 \%$ responden tidak mengetahui bagaimana kegiatan keseharian anggota rumah tangga lain di lingkungan tempat tinggalnya atau dengan kata lain kedalaman jaringannya rendah. Sisanya, sebanyak $23.0 \%$ responden mengaku hanya mengetahui sebagian aktivitas keseharian anggota rumah tangga lain di lingkungan tempat tinggalnya atau bisa dikatakan mempunyai kedalaman jaringan sedang.

Sementara itu, dalam hal pemenuhan pangan, 65.6\% responden mengaku tidak mengetahui apa yang akan dilakukan rumah tangga tetangganya bila sedang dalam kesulitan pangan (kedalaman jaringan rendah). Sisanya $29.5 \%$ rumah tangga miskin responden mengaku mengetahui sebagian kegiatan tetangganya bila tetangganya tersebut sedang mengalami kesulitan dalam pemenuhan pangan (kedalaman jaringan sosial sedang) dan $4.9 \%$ rumah tangga reponden mengaku mengetahui dengan pasti apa yang dilakukan tetangganya bila kesulitan dalam pemenuhan pangan (kedalaman jaringan sosial tinggi), yaitu dengan cara meminjam uang kepada keluarga atau tetangga atau 'nganjuk' di warung dan dikembalikan ketika rumah tangga tersebut sudah mempunyai uang.

Keterbukaan Jaringan Sosial. Suatu sistem masyarakat ada yang bisa menerima kehadiran pihak lain namun ada juga yang tidak bisa menerima kehadiran pihak lain. 
Sistem sosial masyarakat pertama sering dikenal dengan sistem masyarakat terbuka dan sistem masyarakat kedua sering dikenal dengan sistem masyarakat tertutup. Dalam penelitian ini, keterbukaan jaringan dilihat dari bisa tidaknya lingkungan rumah tangga miskin responden dalam menerima kehadiran pihak luar. Hasil yang diperoleh adalah semua responden (100\%) mengaku bahwa lingkungannya terbuka menerima kehadiran pihak luar asalkan tidak menganggu kenyamanan masyarakat. Kondisi ini menunjukkan bahwa komunitas di kedua lokasi penelitian mempunyai jaringan yang terbuka. Hal tersebut tentu saja bisa dimanfaatkan oleh pihak manapun yang ingin membantu memberdayakan rumah tangga miskin di kedua lokasi penelitian.

Salah satu kondisi yang terlihat di kedua lokasi penelitian terkait dengan keterbukaan jaringan adalah adanya anggota masyarakat yang bukan asli penduduk di lingkungan tersebut. Bahkan, rumah tangga miskin responden yang istrinya adalah pendatang atau bukan asli penduduk di lingkungan tersebut justru mempunyai tingkat ketahanan pangan rumah tangga yang lebih baik. Hal ini ditunjukkan dari hasil uji korelasi Spearman antara variabel ketahanan pangan rumah tangga dengan status istri sebagai penduduk pendatang (bukan asli lingkungan tersebut), yang menghasilkan koefisien $0.314^{*}$ (signifikan pada $\alpha=$ 0.05). Kondisi ini dapat terjadi dimungkinkan karena sebagai orang yang bukan asli dari lingkungan tersebut mendorongnya untuk berusaha lebih keras guna memenuhi kebutuhan pangan rumah tangganya.

Permanency Jaringan Sosial. Suatu jaringan yang dibangun oleh pihak-pihak terkait bisa berlangsung secara permanen namun bisa juga hanya bersifat temporal. Hasil penelitian ini menunjukkan bahwa jaringan sosial yang dibangun rumah tangga miskin responden di kedua lokasi penelitian dalam rangka pemenuhan pangan dan pengasuhan balita merupakan jaringan yang bersifat temporal. Rumah tangga miskin responden akan menjalin hubungan pemenuhan pangan dengan rumah tangga lain tidak selamanya, kadangkala saja ketika sedang kesulitan uang atau sekedar saling menukar makanan. Sementara itu, rumah tangga miskin responden yang mempunyai balita akan menitipkan balitanya ke kerabat atau tetangganya di lingkungan tersebut untuk dibantu diasuh, bila sedang pergi untuk bekerja atau ada keperluan yang hanya sebentar.

Norma Sosial. Fedderke et al. (1999) menyatakan bahwa sebuah asosiasi sosial (organisasi sosial) di dalamnya mengandung norma-norma berupa aturan-aturan informal dan nilai-nilai yang memfasilitasi adanya koordinasi di antara anggota dalam sebuah sistem sosial. Hasil penelitian ini menunjukkan bahwa hanya $4.9 \%$ rumah tangga miskin responden yang mengaku mempunyai dasar norma tidak tertulis (aturan-aturan informal) ketika saling membantu dalam pemenuhan kebutuhan pangan rumah tangga dan pengasuhan balita. Norma tersebut berupa kesadaran untuk saling membantu antar tetangga apalagi untuk makan sehari-hari karena masih saudara/kerabat yang harus saling menolong. Aturan-aturan informal yang berbasis aturan tradisional juga ditemukan dalam penelitian ini, meskipun hanya satu rumah tangga miskin responden yang mengaku meyakini adanya norma tradisional dalam menjalin hubungan sosial dan dalam memenuhi kebutuhan pangan sehari-hari. Menurut pengakuan Bapak Rtj (55 tahun), salah satu responden yang berasal dari Kelurahan Kedung Jaya, sudah menjadi tradisi masyarakat Sunda untuk 
'ngariyung' (kumpul bersama), sehingga terdorong untuk saling membantu dalam memenuhi kebutuhan makan. Selain itu, menurutnya, dalam tradisi Sunda anak tetangga itu juga merupakan anak kita sehingga mengasuh anak itu tanggung jawab bersama. Norma agama, khususnya yang didasarkan pada ajaran Islam yang merujuk pada ayat Al-Qur'an bahwa sesama muslim wajib saling membantu, diakui $4.9 \%$ rumah tangga miskin responden sebagai dasar melakukan tindakan sosial baik itu dalam tindakan saling membantu pemenuhan pangan. Mereka mengakui bahwa Islam telah menegaskan adanya kewajiban saling membantu, sehingga apabila ada tetangga yang kesusahan makan, wajib ditolong selama yang dimintai tolong mampu melakukannya

Keragaan norma sosial tersebut menunjukkan bahwa rumah tangga miskin perkotaan di kedua lokasi penelitian masih sedikit sekali yang menyandarkan hubungan sosialnya pada norma-norma sosial baik itu norma tidak tertulis, norma tradisional ataupun norma agama, termasuk di dalamnya sikap menjaga komitmen maupun pemenuhan kewajiban. Padahal norma-norma yang diyakini beberapa responden pada beberapa kasus tersebut, mampu mendorong yang bersangkutan untuk saling membantu antar tetangga baik itu dalam pemenuhan pangan sehari-hari maupun dalam pengasuhan balita. Kesadaran akan norma sosial yang belum tinggi pada rumah tangga miskin di kedua lokasi penelitian mengindikasikan bahwa ketika rumah tangga saling membantu memenuhi kebutuhan pangan ataupun saling membantu mengasuh anak, kemungkinan lebih sekedar karena ada hubungan kerabat atau tetangga. Norma sosial berupa aturan-aturan informal yang sarat dengan sikap menjaga komitmen dan pemenuhan kewajiban masih belum menjadi dasar yang kuat dalam menjalin hubungan sosialnya. Sehingga bisa dikatakan bahwa keberadaan norma sosial di kedua lokasi penelitian masih rendah, baik dalam mengatur hubungan antar rumah tangga untuk saling membantu memenuhi pangan sehari-hari maupun pada waktu saling membantu mengasuh balita.

Berdasarkan mekanisme modal sosial berupa kepercayaan (trust), jaringan sosial (social networks), dan norma sosial (social norms) dalam penguatan ketahanan pangan rumah tangga miskin, menunjukkan bahwa modal sosial di lokasi penelitian mempunyai basis kolektivisme-komunitas. Basis kolektivisme-komunitas dengan landasan etika "bounded solidarity" ini, terlihat dari kasus rumah tangga miskin yang berasal dari daerah yang sama serta hubungan sosial yang lebih dekat antar keluarga luas (kerabat) yang tinggal dalam satu lingkungan tempat tinggal. Hal ini seiring dengan perspektif komunitarian yang dalam mendefinisikan modal sosial mengasumsikan bahwa sistem sosial terikat dalam etika "bounded solidarity" (Woolcok 1998). Etika "Bounded solidarity" yang terbangun tersebut merupakan stok modal sosial yang cukup tinggi dan dalam kondisi tertentu dapat diubah menjadi bentuk modal ekonomi (Bourdie dalam Winter 2000), khususnya berbentuk pangan, yang mana rumah tangga miskin tetap dapat terpenuhi kebutuhan pangannya meskipun mempunyai keterbatasan uang untuk membelinya. Potensi modal ekonomi yang dapat dirubah dari modal sosial yang ada dalam ikatan etika "bounded solidarity" tersebut didasari oleh rasa senasib sepenanggungan ataupun oleh nilai-nilai informal bahwa antar saudara dan tetangga harus saling membantu. Uji statistik menunjukkan bahwa beberapa komponen modal sosial, mempunyai potensi dalam menguatkan ketahanan pangan. Potensi yang tidak dalam bentuk uang 
namun dapat dikonversi menjadi bentuk modal ekonomi guna pemenuhan kebutuhan pangan rumah tangga.

Hanya saja kolektivisme yang terbangun di dalam komunitas, khususnya dalam membantu menguatkan ketahanan pangan antar rumah tangga miskin, masih dalam taraf ikatan antar beberapa rumah tangga karena sama-sama perantau atau karena masih kerabat. Kolektivisme yang muncul belum merupakan aksi kolektivitas semua anggota komunitas dalam satu RW/kelurahan yang sarat denga nilai dan norma yang dibangun bersama, yang kemudian terinternalisasi menjadi bentuk-bentuk kelembagaan. Meskipun begitu, hasil penelitian ini menunjukkan bahwa nilai-nilai saling membantu masih belum seluruhnya pudar dalam lingkungan masyarakat perkotaan, khususnya pada rumah tangga miskin, untuk saling membantu menguatkan ketahanan pangan rumah tangga mereka.

\section{KESIMPULAN}

Kesimpulan hasil penelitian yang disajikan dalam tulisan ini adalah :

1. Keberadaan modal sosial lebih baik di Kelurahan Kedung Jaya.

2. Komponen modal sosial yang berhubungan signifikan dengan ketahanan pangan rumah tangga adalah kepercayaan rumah tangga dalam menjalin hubungan tanpa rasa saling curiga, kepercayaan rumah tangga untuk dapat menjaga lingkungannya tetap sustain, jumlah hubungan sosial yang dimiliki rumah tangga, dan istri yang bukan merupakan penduduk asli di lingkungan tempat tinggal.

3. Modal sosial dapat dikembangkan dan dioptimalkan dalam bentuk kelembagaan-kelembagaan sosial di tingkat komunitas yang dapat menguatkan ketahanan pangan pada rumah tangga miskin, dengan mendasarkan pada bounded solidarity yang telah ada antar rumah tangga.

\section{DAFTAR PUSTAKA}

Agresti A, Finlay B. 1997. Statistical Methods for the Social Sciences. Prentice Hall, Inc: Amerika Serikat.

Atmarita, Fallah TS. 2004. Analisis Situasi Gizi dan Kesehatan Masyarakat. Di dalam : Ketahanan Pangan dan Gizi di Era Otonomi Daerah dan Globalisasi. Prosiding Widyakarya Nasional Pangan dan Gizi VIII; Jakarta, 17-19 Mei 2004. Jakarta : Lembaga Ilmu Pengetahuan Indonesia.

Beall J. 2000. Life in the Cities. Di dalam Allen T, Thomas A, editor : Poverty and Development into the $21^{\text {st }}$ Century. Oxford University Press: New York.

BPS. 2005. Statistik 60 Tahun Indonesia Merdeka. Badan Pusat Statistik. Jakarta.

Brata AG. 2004. Nilai Ekonomis Modal Sosial pada Sektor Informal Perkotaan. Lembaga Penelitian Universitas Atma Jaya: Yogyakarta.

Dharmawan AH. 2002a. Kemiskinan Trust dan Stok Modal Sosial Masyarakat Indonesia Baru. Makalah dibawakan dalam Seminar dan Kongres Nasional IV Ikatan Sosiologi Indonesia. Bogor. 27-29 Agustus 2002. 
Dharmawan AH. 2002b. Kemiskinan Kepercayaan (Trust, Stok Modal Sosial dan Disintegrasi Sosial. Perluasan dari makalah atas topik yang sama yang diajukan dalam Seminar dan Kongres Nasional IV Ikatan Sosiologi Indonesia. Bogor. 27-29 Agustus 2002.

Fedderke J et al. 1999. Economic Growth and Social Capital : A critical Reflection. Kluwer Academic Publishers. Netherlands.

Hikmat H. 2001. Strategi Pemberdayaan Masyarakat. Humaniora Utama: Bandung. http://www.viet-studies.org/Bourdieu_capital.htm [10 Januari 2007].

Kusharto C, Sa'diyyah NY. 2005. Diktat Penilaian Konsumsi Pangan. Departemen Gizi Masyarakat Fakultas Ekologi Manusia. IPB: Bogor.

Mantra IB. 1996. Mobilitas Non Permanen Penduduk. Di dalam Sitorus MTF, Supriono A, Sumarti T, Gunardi, editor : Memahami dan Menanggulangi Kemiskinan di Indonesia (Prof. Dr. Sajogyo 70 Tahun). Grasindo: Jakarta.

Martin KS, Rogers BL, Cook JT, Joseph HM. 2004. Social capital is associated with decreased risk of hunger [abstrak]. Di dalam : Soc Sci Med. Jun;58(12):2645-54.

Maxwell D, Levin C, Armar-Kelemsu M, Ruel M, Morris S, Ahiadeke C. 2000. Urban Livelihoods and Food and Nutrition Security in Grater Accra, Ghana. International Food Policy Research Institute.

Narayan D. 1998. Bonds and Bridges : Social Capital and Poverty. Poverty Group, Prem. World Bank.

Suryana A. 2004a. Ketahanan Pangan di Indonesia. Di dalam : Ketahanan Pangan dan Gizi di Era Otonomi Daerah dan Globalisasi. Prosiding Widyakarya Nasional Pangan dan Gizi VIII; Jakarta, 17-19 Mei 2004. Jakarta : Lembaga Ilmu Pengetahuan Indonesia.

Syahra R, Hanim MS, Kusumawardhani DTP, Manan MA. 2000. Anomie dan Modal Sosial : Memahami Krisis Multi Dimensional. Puslitbang Kemasyarakatan dan Kebudayaan LIPI: Jakarta.

Warren MR, Thompson JP, Saegert S. 2001. The Role of Social Capital in Combating Poverty. Di dalam Saegert S, Thompson JP, Warren MR, editor : Social Capital and Poor Communities. Russel Sage Foundation: New York.

World Bank. 2000. World Development Report 1999/2000. World Bank, Development Economics, World Development Report (DECWD): Washington, D.C.

Woolcock M. 1998. Social capital and economic development: Toward a theoretical synthesis and policy framework. Theory and Society 27: 151-208. Kluwer Academic Publisher.

Winter I. 2000. Towards a theorised understanding of family life and social capital. Working paper No. 21, April 2000. Australian Institute of Family Studies. 


\section{Lampiran 1. Kriteria rumah tangga miskin penerima Bantuan Langsung Tunai (BLT) menurut Badan Pusat Statistik (BPS)}

\begin{tabular}{cll}
\hline No & \multicolumn{1}{c}{ Variabel } & \multicolumn{1}{c}{ Kriteria Rumah Tangga Miskin } \\
\hline 1. & $\begin{array}{l}\text { Luas lantai bangunan tempat } \\
\text { tinggal }\end{array}$ & Kurang dari $8 \mathrm{~m}^{2}$ per orang \\
2. $\begin{array}{l}\text { Jenis lantai bangunan tempat } \\
\text { tinggal }\end{array}$ & Tanah/ bambu/kayu murahan \\
3. Jenis dinding tempat tinggal & $\begin{array}{l}\text { Bambu/rumbia/kayu berkualitas rendah/tembok } \\
\text { tanpa diplester }\end{array}$ \\
Tidak punya/bersama-sama dengan rumah tangga
\end{tabular}

\section{Lampiran 2. Alur penetapan lokasi penelitian}

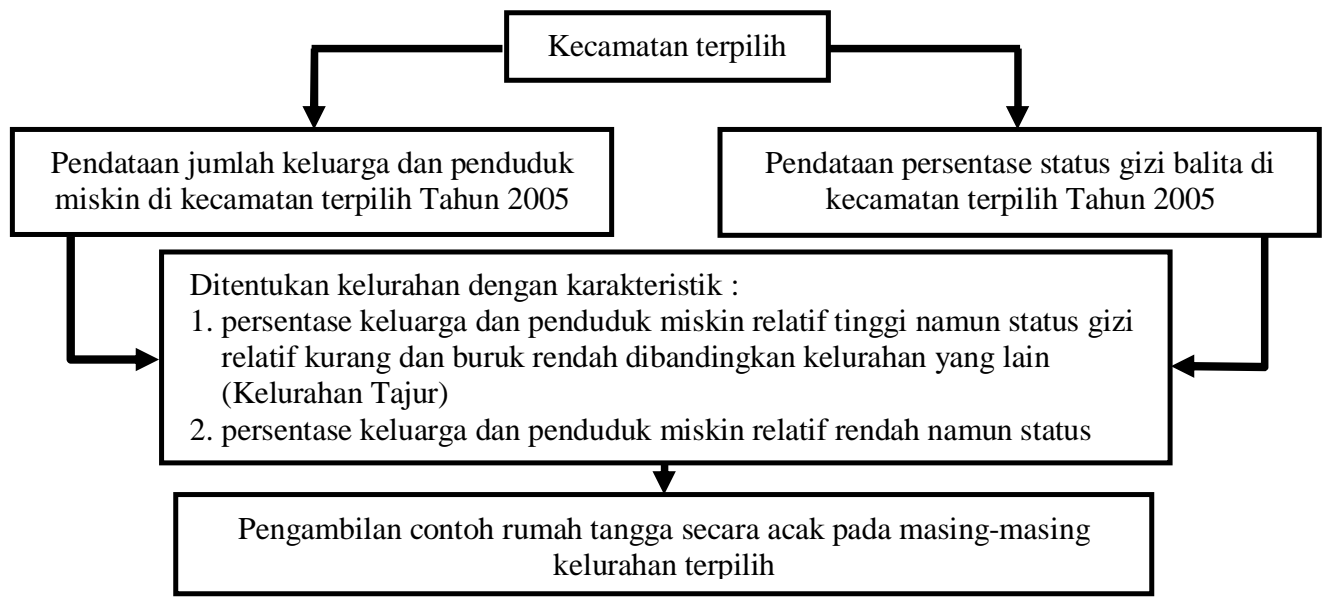


152 | Alfiasari. Modal Sosial dan Ketahanan Pangan Rumah Tangga 